\title{
Uşak-Banaz-Yeşilyurt (Holuz) Köyü Camii ve Kalemişi Bezemeleri
}

\author{
The Usak-Banaz-Yesilyurt (Holuz) Village Mosque and Its Painting Works
}

\section{Şeyda Algaç ${ }^{*}$}

\section{Öz}

İç Ege bölgesi, tasvirli camilerin yoğun olarak gözlemlendiği bölgelerden biridir. Uşak ilinin Banaz ilçesine bağlı Yeşilyurt (Holuz) köyü camii, moloz taş örgüsü, bağdadi kubbenin kullanıldığı ahşap çatı örtüsü, yazı programı, zengin kalemişleri ve kalemişlerini yapan usta adına sahip olması dolayısıyla önemli bir köy camisidir. Kalem işlerinin motif repertuarını vazolara yerleştirilmiş minyatür ağaçlar, sembolik tekke aletleri, kent tasviri, kıvrık dallar üzerine yerleştirilmiş bitkisel bezemeler ve sıvaların altında kalmış olan çeşitli motifler oluşturur. Oldukça tahrip olmuş eser, yıkılmak üzeredir. Mülkiyeti köy tüzel kişiliğine ait olan yapı, İzmir 1 Numaralı Kültür ve Tabiat Varlıklarını Koruma Kurulu tarafından 23.08.1988 tarih ve 463 sayılı kararıyla tescillenmiştir. Kitabesi olmayan caminin kim tarafından ve ne zaman yapıldığı bilinmemesine rağmen bezeme özellikleri değerlendirildiğinde 19. yüzyılın sonlarına doğru yapıldığı ve bezendiği söylenebilir. Makalede yapının mimari özellikleri ve kalemişi bezemeleri detaylı olarak incelenmiş, dönemi içerisindeki yeri ve önemi tespit edilmiştir. Dönemi hakkında önemli ipuçları veren eser, oldukça tahrip olmuş ve yıkılmak üzeredir. Yapı en kısa sürede aslına uygun onarılmalı ve gelecek kuşaklara aktarılmalıdır.

\section{Anahtar Kelimeler}

Kalemişi, Uşak, Banaz, Yeşilyurt (Holuz) Köyü, Cami

\begin{abstract}
The inner Aegean region is an area where mosques with depictions can be seen frequently. Yeşilyurt (Holuz) village mosque in the Banaz district of Uşak province is an important village mosque because it has rubble stone masonry, a wooden roof covering where the lath-and-plaster (bağdadi) dome is used, a writing program, rich painting works (kalemişi), and the name of the master who completed the painting works. The motif repertoire of the painting works consists of miniature trees placed in vases, symbolic religious lodge (tekke) tools, urban depictions, floral decorations placed on curved branches and various motifs that are under the plaster. The structure, which is owned by the village legal entity, is registered with the decision of the Izmir Cultural and Natural Heritage Protection Board No.1 dated 1988 and numbered 463. Although it is not known by whom and when the mosque was built since it does not have an inscription, when its decoration characteristics are evaluated, it can be dated to the end of the 19th century. In the study, the architectural characteristics and painting work decorations of the building have been examined in detail, and its place and importance within its period have been determined. The work, which provides important clues about its period, is significantly ruined and about to collapse. It should be repaired as soon as possible following its original form and passed onto future generations.
\end{abstract}

\section{Keywords}

Painting Works, Usak, Banaz, Yesilyurt (Holuz) Village, Mosque

* Sorumlu Yazar: Şeyda Algaç (Dr. Öğr. Üyesi), Afyon Kocatepe Üniversitesi, Güzel Sanatlar Fakültesi, Geleneksel El Sanatları Bölümü, Afyon, Türkiye. E-posta: seydaalgac@hotmail.com ORCID: 0000-0001-9403-9093

Attf: Algac, Seyda. “Uşak-Banaz-Yeşilyurt (Holuz) Köyü Camii ve Kalemişi Bezemeleri." Art-Sanat, 13 (2020): 1-26. https://doi.org/10.26650/artsanat.2020.13.0001 


\section{Extended Summary}

There were significant changes in Ottoman visual culture with the Westernization movement that started in the first quarter of the 18th century. Unlike the capital city of Istanbul, in many mosques in Anatolia and the Balkans, European-influenced ornamentations and depictions can be observed. The inner Aegean region is one of the areas where mosques with depictions are seen frequently. The structure examined in the study is located in Yeșilyurt (Holuz) Village which is $4.2 \mathrm{~km}$. to the Northwest of the Banaz district of Uşak province. Since the structure does not have an inscription, it is not clear when and by whom it was built.

The mosque was built on a sloping terrain using talus stone and wood material with a wall thickness of $90 \mathrm{~cm}$. Consisting of a square planned harim (prayer hall) and a narthex with three units at the north and the minaret at the north of the western wall, the structure is covered with a roof covered with Marseille-type tiles inclined in four directions. Illuminating the interior area, there are 7 rectangular form windows with wooden jambs in total, two of them on the east, west and south sides and one on the north side. The entrance to the harim is through a wooden door on the north side. The interior floor is made of wood. There is a women s court carried by two wooden columns in the north. The windows with rectangular openings are designed as round arches in the interior area. In the middle of the wooden ceiling, there is a dome made with the lath-and-plaster (bağdadi) technique hidden under the roof. All the internal walls of the building are plastered with white plaster, which has fallen in some parts and the stone-wood material has been exposed. Crescent-shaped decorations are placed on the round-arched windows. The interior walls are divided into three sections with horizontal stripes and the bottom and middle sections are covered with paint. The remaining painting works (kalemişi) in the top section are untouched. There is a semi-circular section mihrab niche in the middle of the south wall. Cypress trees, lemon and apple trees in vases are placed on the top die plate. Among the decorations, there are "Allah (God)", "Muhammad", and «Maşallah (as the God demands)» words and various verses, hadiths and prayer sentences. "Hatip Mustafa Efendi" is written in a rectangular die plate on the western part of the wall. There are a city depiction and a timetable indicating a period of two weeks under partially fallen plaster in the middle part of the eastern wall. Under the timetable, the years from 1318 to 1325 are written orderly. On the upper part of the eastern wall, there are the names bu «Abu Bakr", "Omar", "Osman", "Ali", "Bilal-i Habeshi» and various hadiths. On the upper part of the western wall, there are the names of «Hasan», "Husain», "Veysal Karani”, "Ashâb-1 Kehf (Seven Sleepers)» and several prayer sentences are written. The northern wall is completely painted. Only above the door, there is the expression of «Bu dergâh Allaha itaat için inşâ edildi (This dervish lodge was built for obedience to God)» in Persian. The interior of the dome, which is hidden under the wooden roof covering the harim (prayer hall) place and made with the lath-and-plaster technique, 
is plastered with white plaster and decorated with painting works. On the plinths of the dome, "Ayet al-Kürsi (Lectern Verse)" is written with black thuluth (sülüs) script. Cypress, various trees placed in vases, a European style clock, and religious lodge (tekke) tools such as poleax and bowl (keşkül) are located within the dome. Although the narthex is completely painted, the existence of decorative painting work can be seen under the fallen paint.

The construction can be considered as a structure, which was architecturally constructed using talus stone and wood material, having a narthex on the north, a minaret on the northwest, the main entrance of which is on the north and on the same axis as the mihrab, with a rectangular plan in north-south direction, covered with Marseille tiles, a hipped roof, with a wooden lath-and-plaster dome without any support under the roof, which was taken in from the main outer walls. These types of lath-and-plaster domed structures, which were taken from the walls of the harim (prayer hall) and hidden under the wooden roof, were frequently used in Ottoman architecture. They are widely seen in civil architectural works such as houses, mansions, and palaces between the end of the 16th century and the beginning of the 19th century. These types of domes, which seem to have a civilian architectural background, were also used in the ceremonial places of the structures of religious sects (tarikat) or in structures with a double function in the style of masjid - religious lodge, mosque - religious lodge. Lath-and-plaster domes are geographically seen in the Balkans and throughout Anatolia but are mostly seen in the Black Sea region, where wood is abundant and economical. The Aegean region comes second in terms of incidence. A writing program that can be seen in many religious places was used in the building. Most of the painting works were subsequently covered. The ones which were able to survive are the herbal motifs that can always be seen in religious places, the clock depiction used in interior decoration during the westernization period, and the religious lodge tools such as poleax and bowl. These types of religious lodge symbols have often been used in architecture since the 2nd Mahmud period with the influence of the fashion created in society by the Ottoman coat of arms, which took its final shape together with the Tanzimat (Reorganization) in the Sultan Abdülmecid period. The depictions of belongings of the religious lodge culture are seen in many religious buildings such as mosques and tombs, especially in the Middle Black Sea region. In the Aegean Region, such symbols are observed in many buildings, especially in village mosques.

The mosque of Banaz Yeşilyurt (Holuz) village is a product of local architecture with its materials, plan, and decorative painting works (kalemişi). Although the building does not have a building inscription, it can be said that the painting works (kalemişi) of the building were made in the late 19th century considering the motifs used in the painting works and the years written in order from $1318(1900 / 1901)$ to 1325 $(1907 / 1908)$ on the eastern wall. The person responsible for the painting works (kale- 
mişi) must be "Hatip Mustafa Efendi" whose name is specified on the western part of the south wall. Considering the dervish lodge symbols used in the dome together with the expression of "dervish lodge (dergâh)" above the door on the northern facade, the writing program of the structure and the lath-and-plaster dome hidden under the roof, it can be thought that the building had a second function such as a "tevhidhane (religious ceremony place)" in addition to the mosque function prior to 1925, the date of the closure of the religious lodges. The building has extraordinary characteristics as a village mosque. It should be restored as soon as possible following its original form and passed onto future generations. The structure should be re-evaluated in the light of new findings to be obtained after the restoration. 


\section{Giriş}

Yapı, Uşak ilinin Banaz ilçesinin ${ }^{1}$ kuzeybatı yönünde ve 4,2 km. uzaklığındaki Yeşilyurt (Holuz) köyünde bulunmaktadır. Köyle ilgili ilk yazılı kaynaklar 16. yüzyılın başlarına aittir. II. Bayezid devrine ait Mufassal Tahrir Defterlerinde Uşak köylerinin nüfus dökümleri detaylı olarak verilmiş, 1520 tarihli defterde köyün adı "Karye-i Falos" olarak belirtilmiștir. Bu tarihte köy, Banaz'a bağlıyken, 1570 senesine ait defterlerde Uşak'a bağl1 görünmektedir. ${ }^{2}$ Uşak Şer'iyye Sicilleri'nde Uşak ve Banaz kazasına ait Tevzi defterlerinde ise köyün adı "Folus" olarak geçmektedir. ${ }^{3} 1933$ tarihinde yayınlanan Köylerimiz adlı eserde ise köyün adı, "Folos (Küçük Oturak)" olarak belirtilmiştir. Bu tarihlerde köy, Uşak kazasına, Uşak kazası da Kütahya vilayetine bağlıdır. ${ }^{4}$ Köyün adı zamanla Holus (Holuz)'a dönüşmüş, Cumhuriyet döneminde de Yeşilyurt olmuştur. Yapının kitabesi olmadığından ne zaman ve kimin tarafından yaptırıldığı belli değildir. Mülkiyeti köy tüzel kişiliğine ait olan eser, İzmir 1 Numaralı Kültür ve Tabiat Varlıklarını Koruma Kurulu tarafindan 23.08. 1988 tarih ve 463 sayılı kararıyla tescillenmiştir. ${ }^{5}$

\section{Mimari Tanım}

Eğimli bir araziye moloz taş ve ahşap malzemeyle $90 \mathrm{~cm}$. duvar kalınlığında inşa edilen, dış duvarlarında sıvası olmayan, doğal örgüsü görülebilen yapının sadece kuzey cephesi beyaz alçıyla sıvanmıştır (G. 1, G. 2). Kare planlı bir harim ile kuzeyde üç birimli son cemaat yeri ve batı duvarının kuzeyinde duvara bitişik minareden oluşan yap1, dört yöne eğimli Marsilya tipi kiremitle kaplı kırma çatıyla örtülüdür (G. 3). ${ }^{6}$ Duvarlardan $70 \mathrm{~cm}$. kadar çıkıntı oluşturan ahşap saçak, yapıyı dört taraftan kuşatır. Doğu, batı ve güney cephelerinde ikişer, kuzey cephesinde bir olmak üzere dikdörtgen formlu, ahşap söveli toplam 7 adet pencere bulunur. Pencereler, dıştan "S" şeklinde işlenmiş zarif demir parmaklıklarla kapatılmıştır. Kuzey batı köşesinde bulunan minare, moloz taştan yuvarlak şeklinde örülmüş bir kaidenin üzerine ahşaptan inşa edilmiştir (G. 4). Konik külahlı ve tek şerefeli minare yıkılmak üzeredir. Kuzeyde yuvarlak kemerli üç açıklıklı olarak düzenlenen son cemaat yerinin yan cepheleri kapalıdır. Kemerler, ikisi duvarlarda ve ikisi ortada olmak üzere dört ahşap sütunla taşınmaktadır.

1 Mustafa Murat Öntuğ, "Osmanlıdan Cumhuriyete Banaz," Afyon Kocatepe Üniversitesi Sosyal Bilimler Dergisi 3/2, (2001): 41- 55.

2 Mehtap Özdeğer, 15-16. Yüzyll Arşiv Kaynaklarına Göre Uşak Kazasının Sosyal ve Ekonomik Tarihi (İstanbul: Filiz Kitabevi, 2001), 228.

3 Öntuğ, "Osmanlıdan Cumhuriyete Banaz," 48, 52.

4 Dahiliye Vekâleti, Köylerimiz (İstanbul: Matbaacılık ve Neşriyat Türk Anonim Şirketi, 1933), 261.

5 Komisyon, UŞAK Kültürel Değerler Yapı Envanteri (İzmir: Uşak Valiliği İl Kültür ve Turizm Müdürlüğü Yayınları, 2007), 186; Kütahya Kültür Varlıklarını Koruma Bölge Kurulu Müdürlüğü, Arşiv Kaydı, envanter no: $64.01 / 2$

6 Makalede kullanılan tüm çizim ve fotoğraflar yazara aittir. Arazi çalışmalarına ve planın hazırlanmasına yardım eden Yüksek Lisans öğrencilerim Mimar Fazilet Çoban ve Mimar Ümit Özbunar’a teşekkür ederim. 


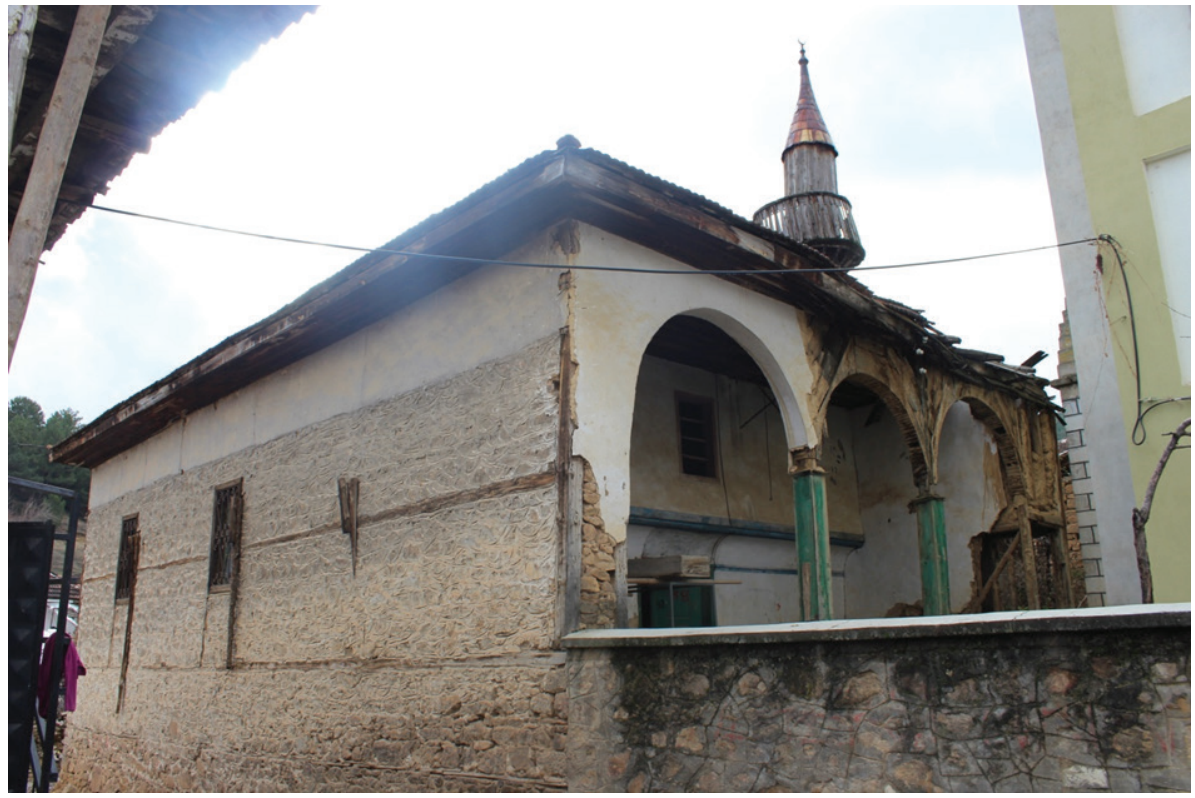

G. 1. Banaz Yeşilyurt Köyü Camii, kuzey ve doğu cephe (Şeyda Algaç, 2019)

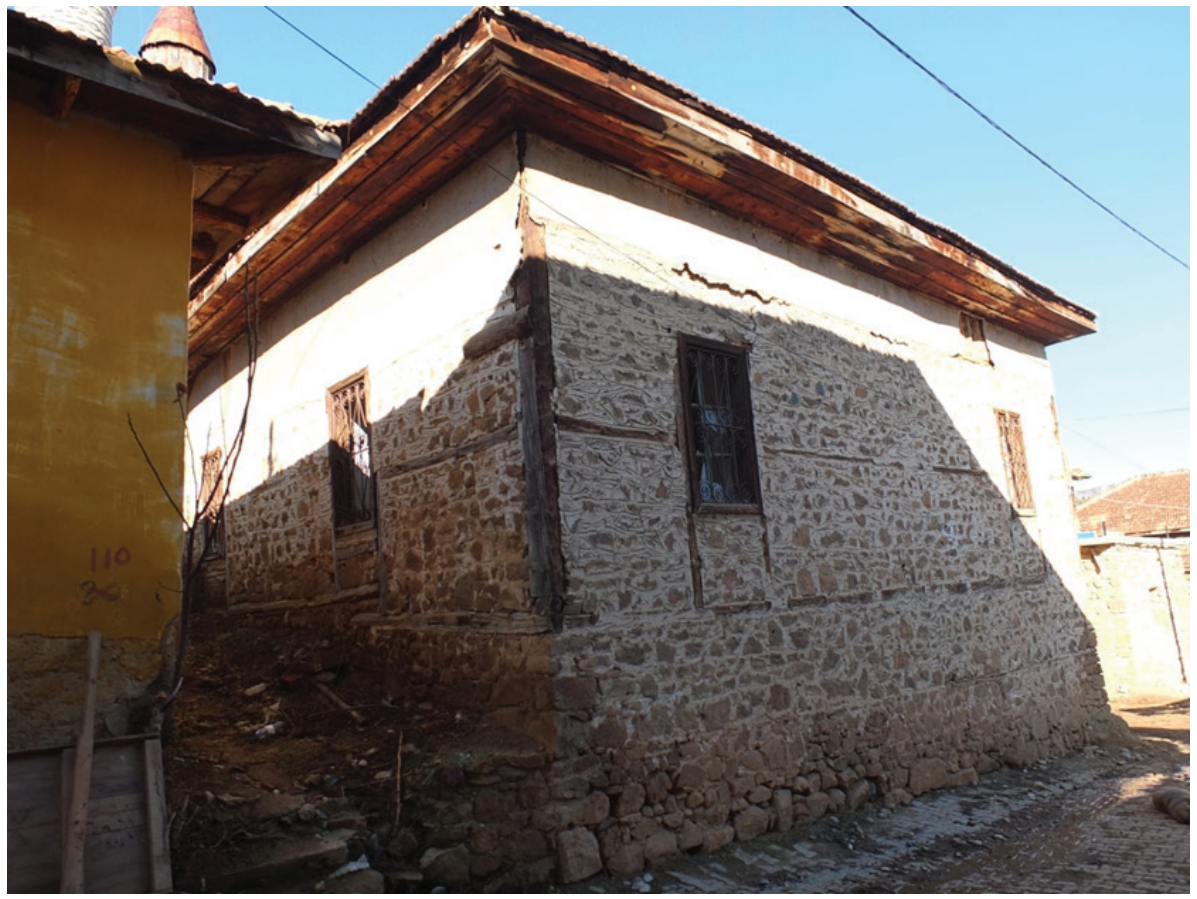

G. 2. Banaz Yeşilyurt Köyü Camii, güney ve batı cephe (Şeyda Algaç, 2019) 


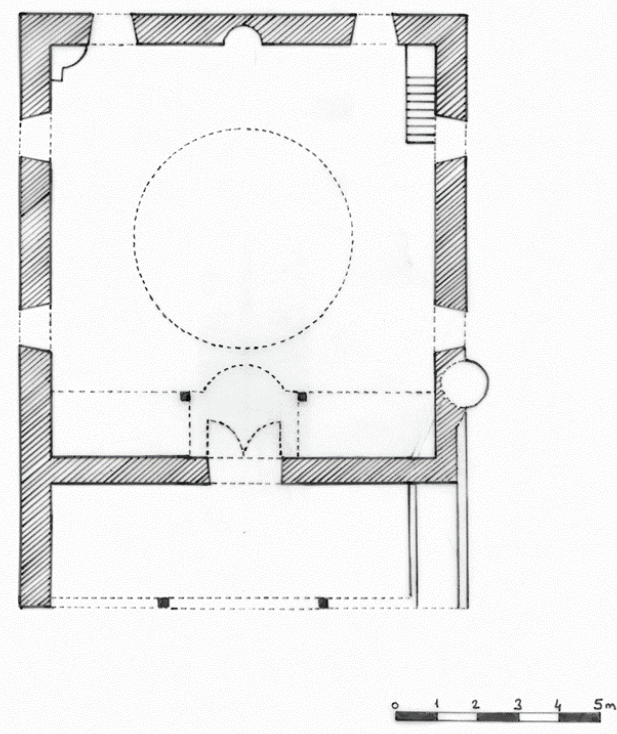

G. 3. Banaz Yeşilyurt Köyü Camii Planı (Şeyda Algaç, 2019)

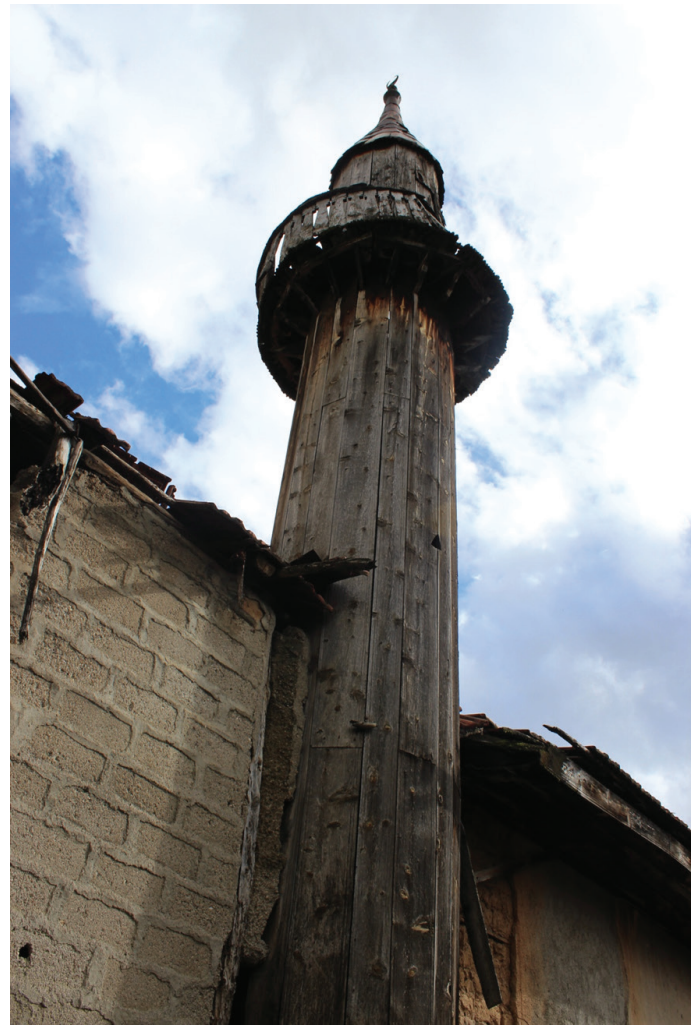

G. 4. Banaz Yeşilyurt Köyü Camii, ahşap minare (Şeyda Algaç, 2019) 
Harim kısmına kuzey cephesinin tam ortasında bulunan iki kanatlı ahşap bir kapıdan girilmektedir. İç mekânın zemini ahşaptır ve zeminde yer yer göçükler oluşmuştur. Kuzeyde ahşap iki sütunla taşınan ahşap kadınlar mahfili bulunur. Kadınlar mahfiline çıkışı sağlayan, muhtemelen kuzeybatı köşesindeki, merdiven yok olmuştur. Mahfilin korkulukları alternatif olarak kırmızı ve siyahla renklendirilmiştir ve tam ortada harime doğru yarım daire şeklinde çıkıntı yapan küçük bir balkon, kuzey duvarının tam ortasında da dikdörtgen bir pencere bulunur. Dikdörtgen açıklıklı pencerelerin üstleri iç mekânda yuvarlak kemerli olarak düzenlenmiştir. Ahşaptan yapılmış tavanın ortasında, çatının altına gizlenmiş, bağdadi bir kubbe vardır. Kubbenin içi beyaz alçıyla sıvanmış ve kalem işleriyle bezenmiştir. Güneybatı köşesinde sade, yeşile boyanmış ahşap minber, güneydoğu köşesinde sade yeşile boyanmış ahşap bir vaaz kürsüsü bulunmaktadır. Yapının tüm iç duvarları beyaz alçıyla sıvanmıştır ancak bu sıvalar bazı bölümlerde döküldüğü için, taş- ahşaptan oluşan duvarın örgüsü ortaya çıkmıştır.

\section{İç Mekân Bezemeleri}

İç mekânın tüm duvarları beyaz alçıyla kaplanmış, üstte mavi bir şerit, altta zigzaglı kalın bir şeritle yatay olarak üçe bölünmüștür. Üstte kalan 1/3'lük alandaki kalemișleri korunarak günümüze kadar özgün hâliyle gelebilmiştir. Altta kalan 2/3'lük alan ve pencere pervazlarıysa beyaz kireçle kapatılmıştır. Güney, doğu ve batı duvarlardaki yuvarlak kemerli pencerelerin üstlerine hilal formunda siyah tahrirli ve sarı zeminli kıvrık dallar yerleştirilmiştir (G. 5). Pencere iç pervazlarında bulunan kalemişi bezemelerse beyaz kireçle kapatılmıştır.

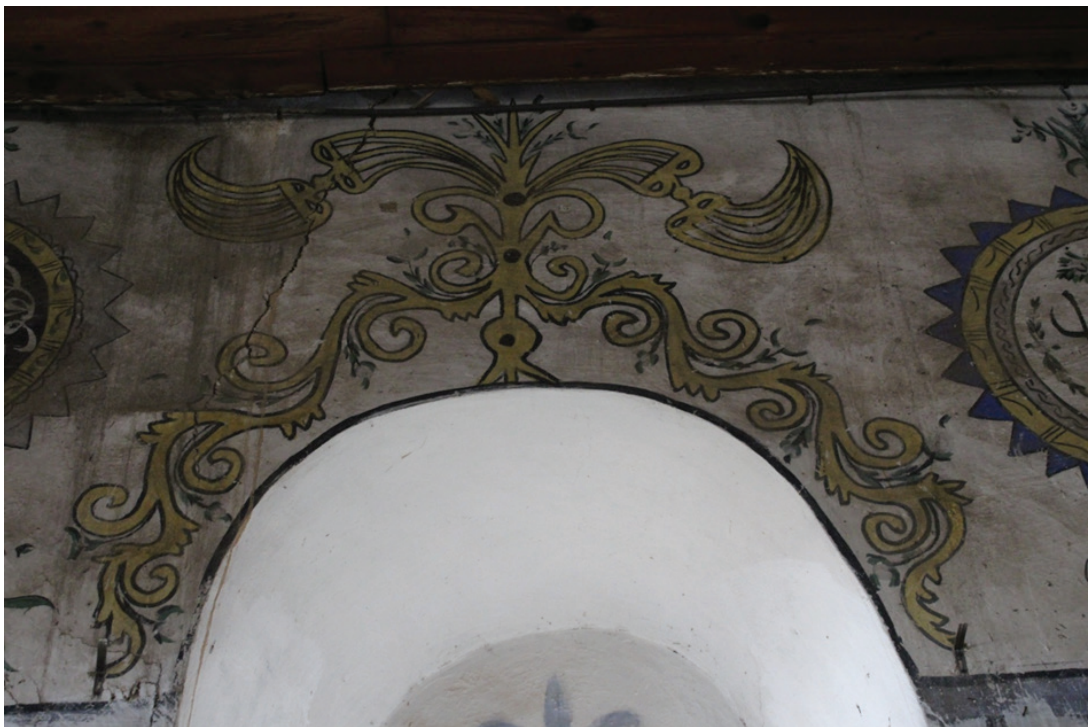

G. 5. Banaz Yeşilyurt Köyü Camii, pencere üstü bezemeleri (Şeyda Algaç, 2019) 
Harimin güney duvarının tam ortasında yarım daire kesitli bir niş şeklinde düzenlenmiş mihrap bulunur. Mihrap nişinin dışında beyazlı, kahverengili, zigzaglı bir bordür vardır. Mihrabın ortasında yarım daire şeklinde paftalar, üstte de muhtemelen sonradan eklenmiş yeşil dikdörtgen düz bir pafta bulunur. Yeşil dikdörtgen paftanın üstünde kare bir bölüm vardır. Karenin köşelerine simetrik olarak Allah lafzı yazılmıştır. Yanlardaki çeyrek daire şeklindeki paftalara siyah-beyaz renkli yelpaze şeklinde bezemeler yapılmış, kare paftanın üstüne de su damlası şeklinde tasarlanmış besmele ibaresi yazılmıştır. Mihrabın üstünde Âl-i Imran suresinin 37. ayetinden bir bölüm Küllemâ dehale aleyhâ Zekeriyya el mihrâb, onun üstünde de vazo şeklinde düzenlenmiş Mâşâallah ifadesi bulunur. Vazoya kırmızı güle benzer çiçekler, yeşil yaprak ve dallar yerleştirilmiştir. Mihrabın sağ üst köşesine beyaz zeminli bir daire içine Allah (c.c.), sol üst köşesine Muhammed (s.a.v) yazılmıştır. Dairelerin dışında gri ve sarı renkli düz ince bordürler bulunur. Daireler en dışta 1şınsal şekilde yerleştirilmiş küçük lacivert üçgenlerle nihayetlenir. Allah lafzının altındaki lacivert zeminli yatay dikdörtgen paftaya siyah tahrirli sarı renkli sülüsle bir çeşit Hıfz (Korunma) duasının bir bölümü Yâ Hâfiyye'l- eltâf neccinâ mimma nehâf (Ey gizli lutûflar sahibi olan Allah'ım bizi korktuklarımızdan koru), Muhammed (s.a.v) ibaresinin altındaki lacivert zeminli dikdörtgen paftayaysa Fetih suresinin birinci ayeti yazılmıştır. Allah ve Muhammed ibarelerinin mihraba doğru olan taraflarına boğumlu birer servi, pencere taraflarına ise düz birer servi yerleştirilmiş̧ir. Duvarın doğu tarafındaki penceresiyle doğu duvarı arasına ayaklı ve kulplu lacivert bir vazonun içine sarı meyveleri olan minyatür bir ağaç, duvarın batı tarafındaki penceresinin sol üst tarafına ise ayaklı ve kulplu lacivert bir vazonun içine kırmızı meyveleri olan minyatür bir ağaç yerleştirilmiştir. Pencerenin sağ tarafındaysa dikdörtgen bir paftanın içinde Hatib Mustafa Efendi yazısı okunmaktadır. Duvarın ortada kalan 1/3'lük kesiminde mihrabın doğusunda kalan bölümünün boyaları yer yer dökülmüştür. Dökülen boyaların altından şamdan, ibrik gibi motifler güçlükle seçilebilmektedir (G. 6 ve G. 7). 


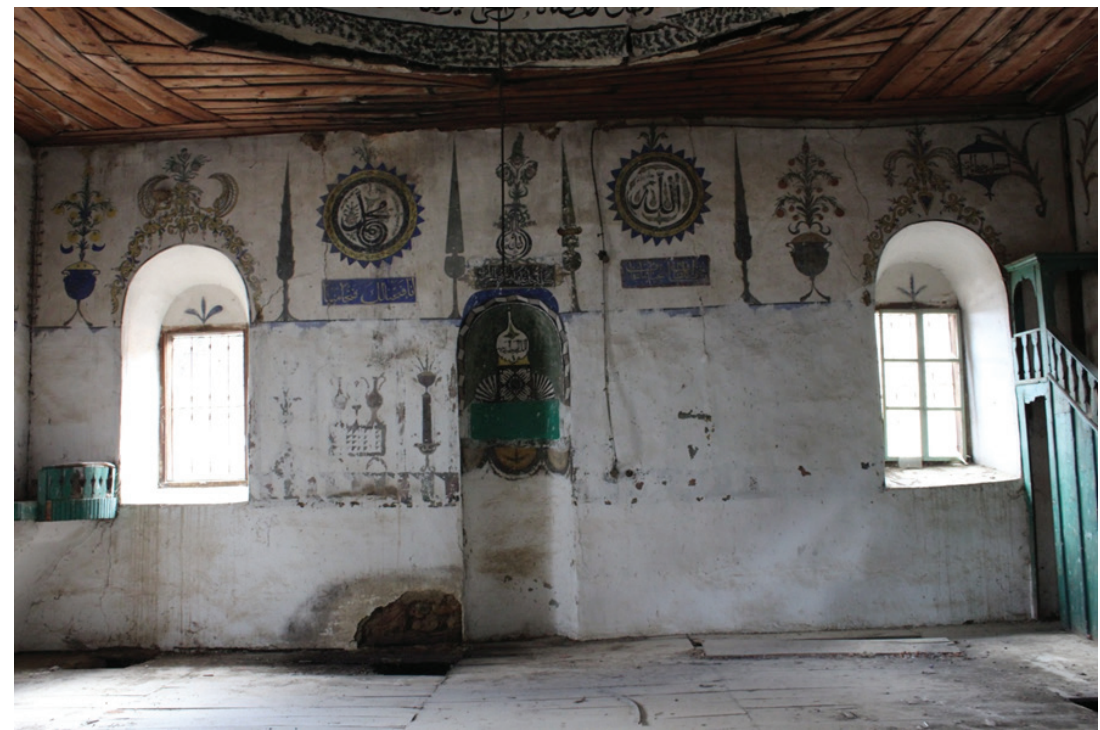

G. 6. Banaz Yeşilyurt Köyü Camii, güney (mihrap) duvarı (Şeyda Algaç, 2019)

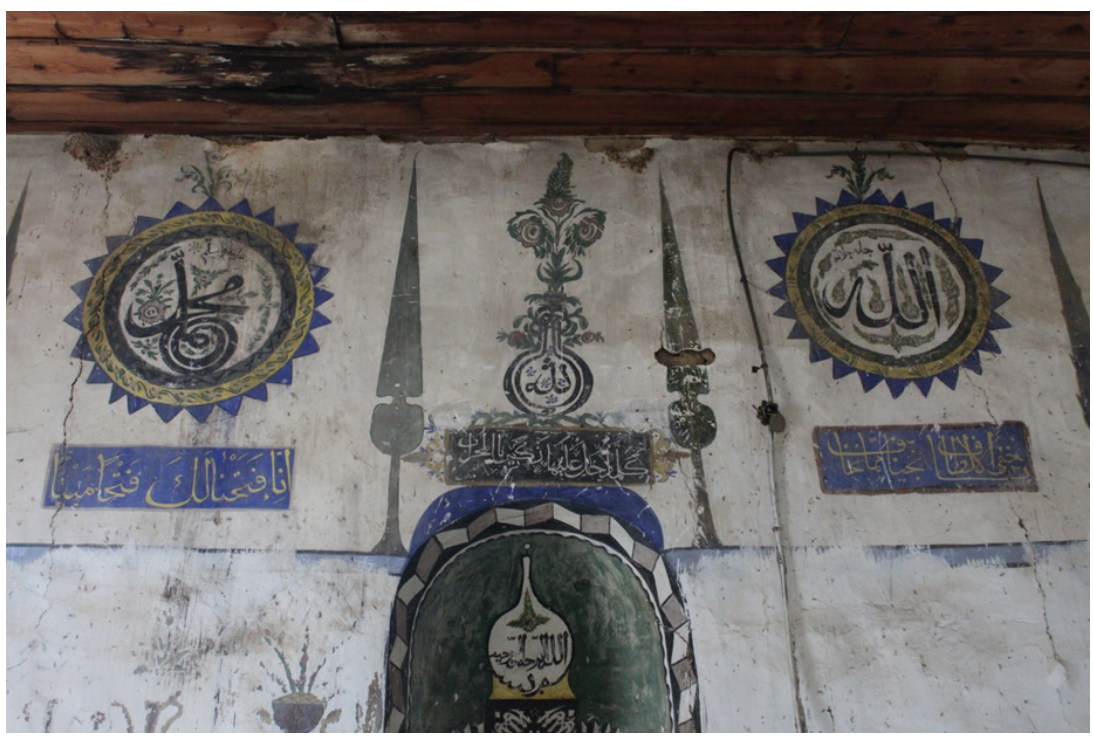

G. 7. Banaz Yeşilyurt Köyü Camii, güney duvarı, ayrıntı (Şeyda Algaç, 2019)

Doğu duvarında yukarıda kalan 1/3'lük bölüme beyaz zeminli daireler içine güneyden kuzeye doğru sirayla Ebû Bekir (r.a.), Ömer (r.a.), Osman (r.a.), Ali (r.a.) yazılmıştır. Dairelerin çevresini sarı ve yeşil zeminli bordürler çevirir. Daireler en dışta 1şınsal şekilde yerleştirilmiş lacivert küçük üçgenlerle nihayetlenir. Ebû Bekir ismi ile Ömer ismi ve Osman ismi ile Ali ismi arasında yuvarlak kemerli dikdörtgen pencereler bulunur. Güney yönünde olan pencerenin üstüne siyah tahrirli ve sarı ze- 
minli kıvrık dallar yerleştirilmiştir. Kıvrık dallar üstte her iki yana doğru zemini üçgen peteklerle doldurulmuş, hilale benzeyen birer motifle sonuçlandırılmıştır. Sarı zeminli kıvrık dalların arasında siyah ince dallar dolanır. Kuzey yönünde olan pencerenin üstüyse benzer üslupla ancak daha basit olarak süslenmiştir. Eb̂̂ Bekir ve Ali isimlerinin altında kıvrık dallı, yeşil, basit yapraklar bulunur. Ömer isminin altına dikdörtgen pafta içine Ed-dünya cîfetûn ve tâlibuhâ kilâbun (Dünya kokmuş bir leştir, onun peşinde olanlar ise köpeklerdir), Osman isminin altına El kânaatü kenzi min künûz Allah (Allahın hazinelerinden kanaat, tükenmez bir hazinedir) hadisi yazılmıştır. Ömer ile Osman isimleri arasında kalan kareye yakın dikdörtgen paftayaysa Bilâl- $i$ Habeşi, üstüne su damlası formu oluşturacak şekilde Fe-tebârekallah (Her türlü hayrın sahibi Allah çok yüce ve noksanlıklardan münezzehtir) yazılmıştır (G. 8). Duvarın orta bölümünde kalan 1/3'lük kısmındaki kalemişleri kapatılmış olmasına rağmen dökülen boyaların altından bazı kalemişleri görülebilmektedir. Güneyden kuzeye doğru bir kent tasviri (G. 9) ve iki haftalık sürenin günleriyle belirtildiği bir zaman cetveli bulunur (G. 10). Cetvelin altında 1318 'den 1325 'e kadar olan yıllar sırayla yazılmıştır.

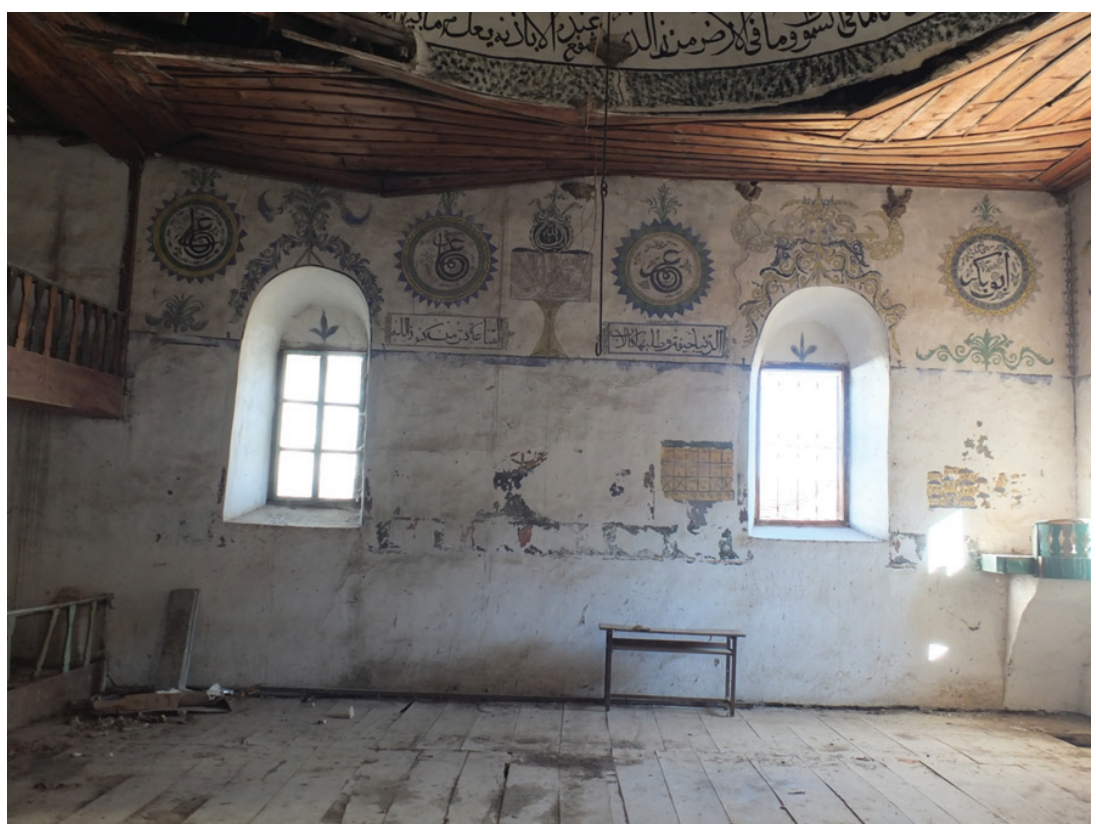

G. 8. Banaz Yeşilyurt Köyü Camii, doğu duvarı (Şeyda Algaç, 2019) 


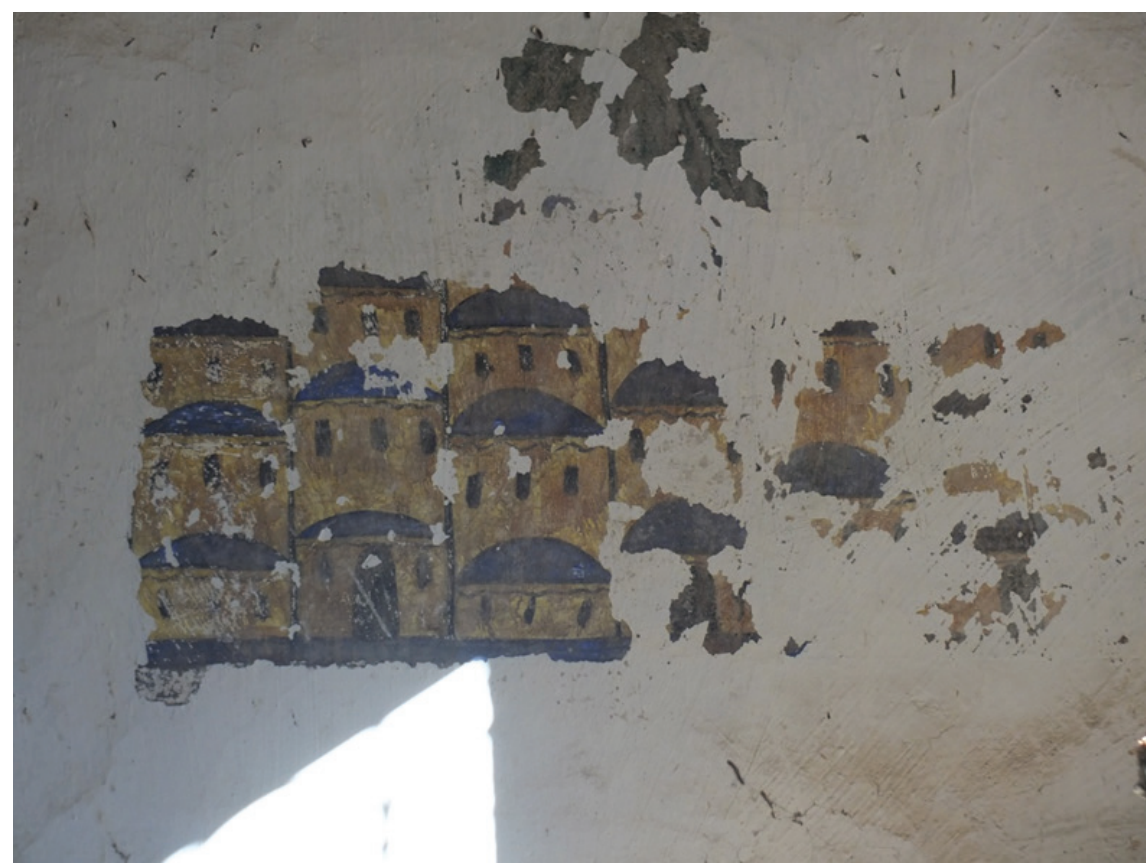

G. 9. Banaz Yeşilyurt Köyü Camii, doğu duvarı, ayrıntı (Şeyda Algaç, 2019)

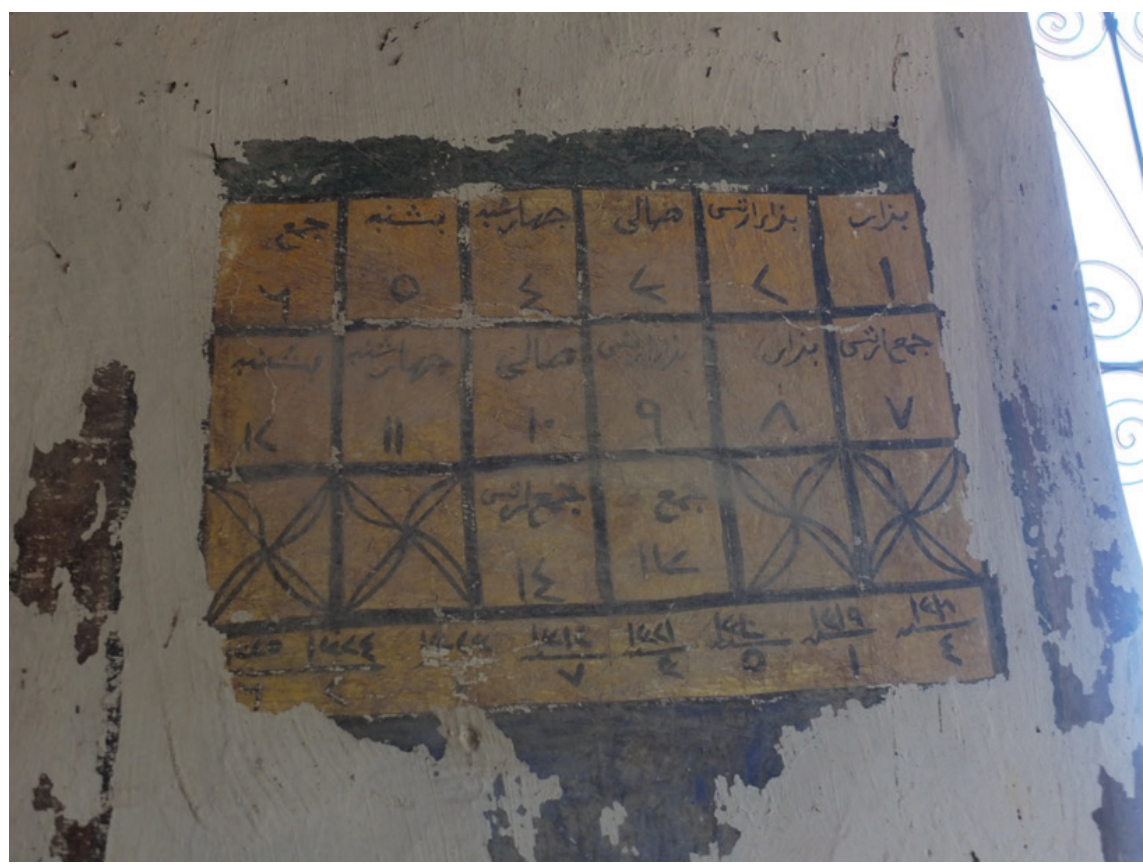

G. 10. Banaz Yeşilyurt Köyü Camii, doğu duvarı, ayrıntı (Şeyda Algaç, 2019) 
Batı duvarında yukarıda kalan 1/3'lük bölüme beyaz zeminli daireler içine kuzeyden güneye doğru sırayla Hasan, Hüseyin, Yâ Kâziye'l-hâcat (Ey bütün ihtiyaçları karşılayan Rabbimiz, bizim ihtiyaçlarımızı da karşıla) yazılmıştır. Daireler en dışta gri, sarı, ince bordürler ve 1şınsal olarak düzenlenmiş lacivert, küçük üçgenlerle sonuçlanır. En sonda Ashâb-ı Kehf isimleri Mühr-ü Süleyman şeklinde düzenlenmiş, mührün ortasına simetrik bir çifte Muhammed (s.a.v) yerleştirilmiştir. Hüseyin ismi ile Ya Kâziye'l- hâcat ibaresinin arasına dikdörtgen bir pafta içine Veysel Karani yazılmış, üzerine kulplu yarım bir vazo içine sarı meyveleri olan minyatür bir ağaç oturtulmuştur. Yazıların altında ve bölümün çeşitli boşluklarında kıvrık dallar üzerine yerleştirilmiş yeşil yapraklı bezemeler bulunur. Yuvarlak kemerli pencerelerin üzerleri diğer pencerelerin üstü gibi benzer bir üslupla süslenmiştir (G. 11).

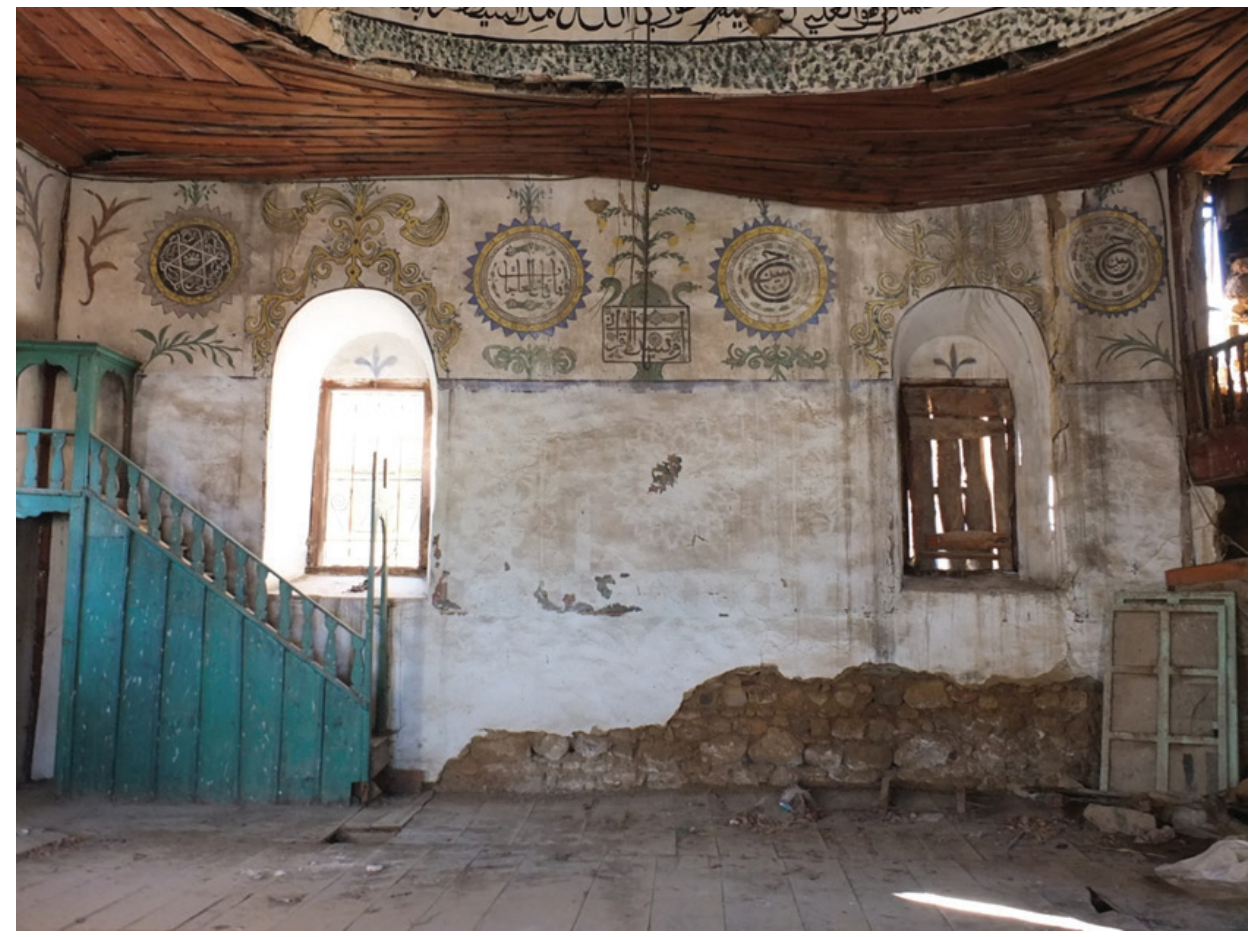

G. 11. Banaz Yeşilyurt Köyü Camii, batı duvarı (Şeyda Algaç, 2019)

Kuzey duvarı tamamen beyaz kireçle kapatılmıştır. Boyanın altında kalan süslemeler güçlükle gözlemlenebilmektedir (G. 12). Duvarın ortasında bulunan kapının üzerinde mekândan çıkarken okunabilecek Farsça Küşâd bâd bi tâat hemîşe in dergâh (Bu dergâh Allah'a itaat için inşa edildi) ibaresi bulunur (G. 13). 


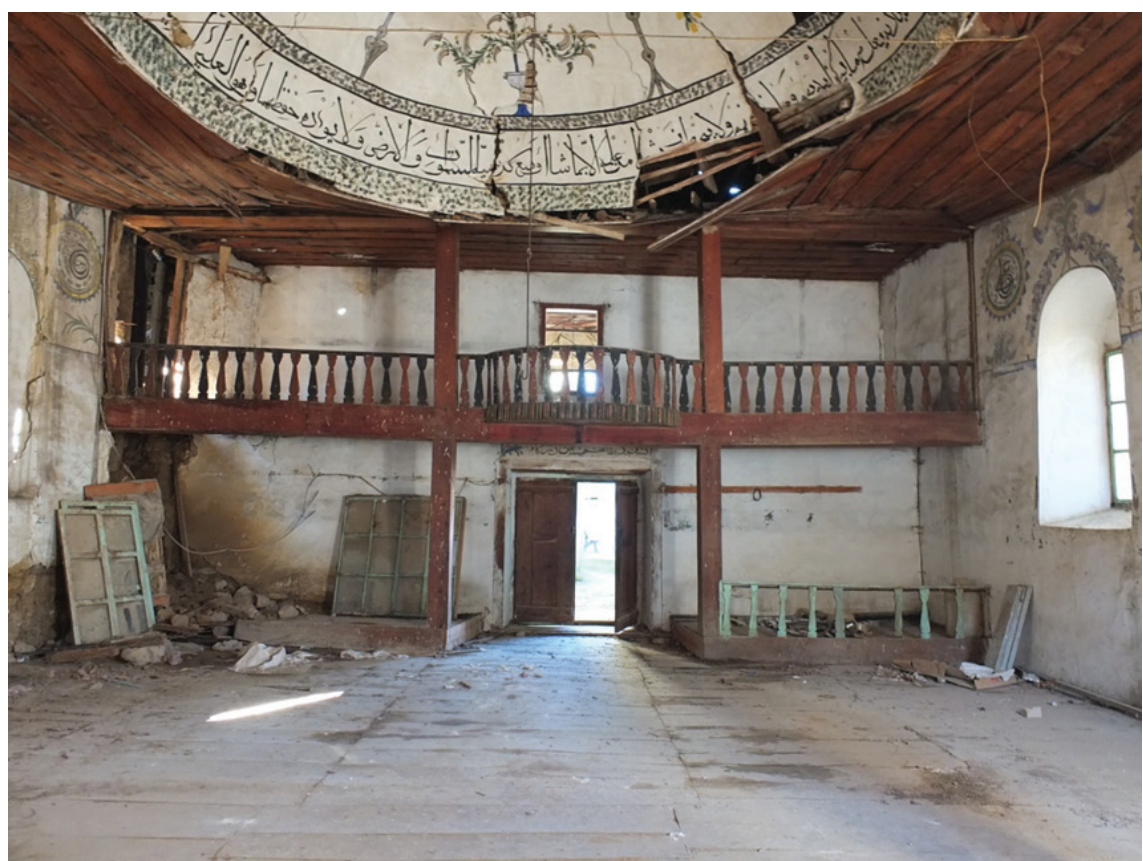

G. 12. Banaz Yeşilyurt Köyü Camii, kuzey duvarı (Şeyda Algaç, 2019)

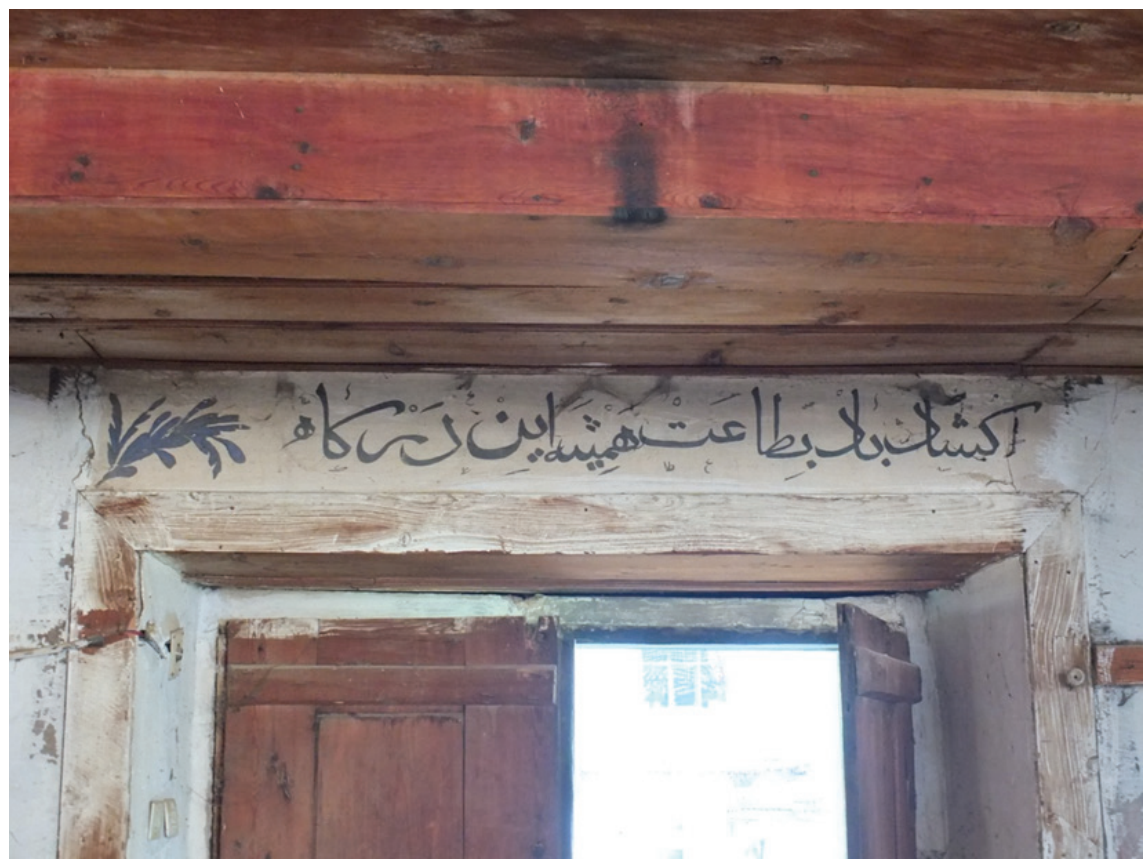

G. 13. Banaz Yeşilyurt Köyü Camii, kuzey duvarı, ayrıntı (Şeyda Algaç, 2019) 
Harim mekânının üstünü örten, ahşap çatı altına gizlenmiş, bağdadi kubbenin içi, beyaz alçıyla sıvanarak, kalemişleriyle bezenmiştir (G. 14). Kubbenin eteklerine siyah konturlu, içleri siyah bulutumsu bir ince, bir kalın bordür geçirilmiş, bordürlerin arasında kalan beyaz zeminli geniş bölüme siyah renkli sülüs yazıyla Ayete'l-Kürsi yazılmıştır. Kubbenin merkezinde siyah zeminli bir daire içine altı kollu, siyah bir yıldız yerleştirilmiş, dilimlerin arasında oluşan beyaz üçgenlerin merkezine yeşil renkli küçük pençler oturtulmuştur. Merkezdeki bu daire en dişta mavi bir bordürle sonuçlanır. Kubbenin merkezinden dışarı doğru hayalî on eksen çizilmiş, eksenlere sırasıyla siyah bir servi, içinde minyatür bir gül ağacının olduğu kulplu ve ayaklı mavi bir vazo, uzunca bir sapa sahip olan bir teber, rakamları Arap rakamlarıyla belirlenmiş Avrupai bir saat (G. 15), ucu mızrak şekline dönüştürülmüş bir servi, içinde minyatür bir limon ağacı bulunan kulplu ve ayaklı gri bir vazo, ucunda siyah topa benzeyen bir nesne bulunan ve ne olduğu anlaşılamayan bir cisim, içinde minyatür bir ağaç bulunan kulplu ve ayaklı bir vazo (G. 16), ucu mızrak şeklindeki bir sopanın kenarına iliştirilmiş mavi bir keşkül, içinde sar1-yeşil renkli minyatür bir ağacın bulunduğu kulplu ve ayaklı mavi bir vazo yerleştirilmiştir. Son cemaat yeri beyaz kireçle boyanmış olmasına rağmen bu bölümde de kalemişlerinin olduğu dökülen boyaların altından görülen bezemelerden anlaşılmaktadır.

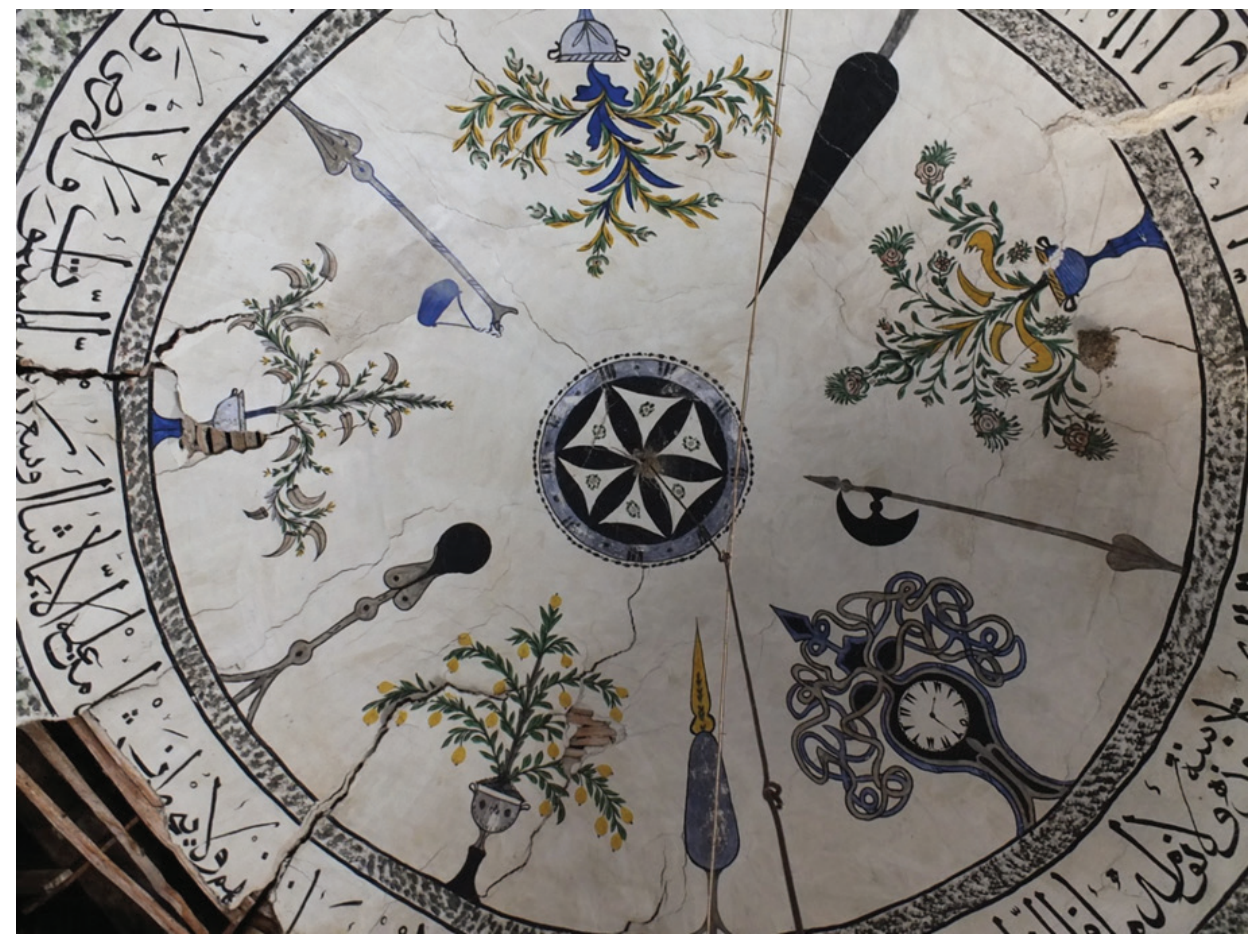

G. 14. Banaz Yeşilyurt Köyü Cami, bağdadi kubbe, kalemişi bezemeleri (Şeyda Algaç, 2019) 


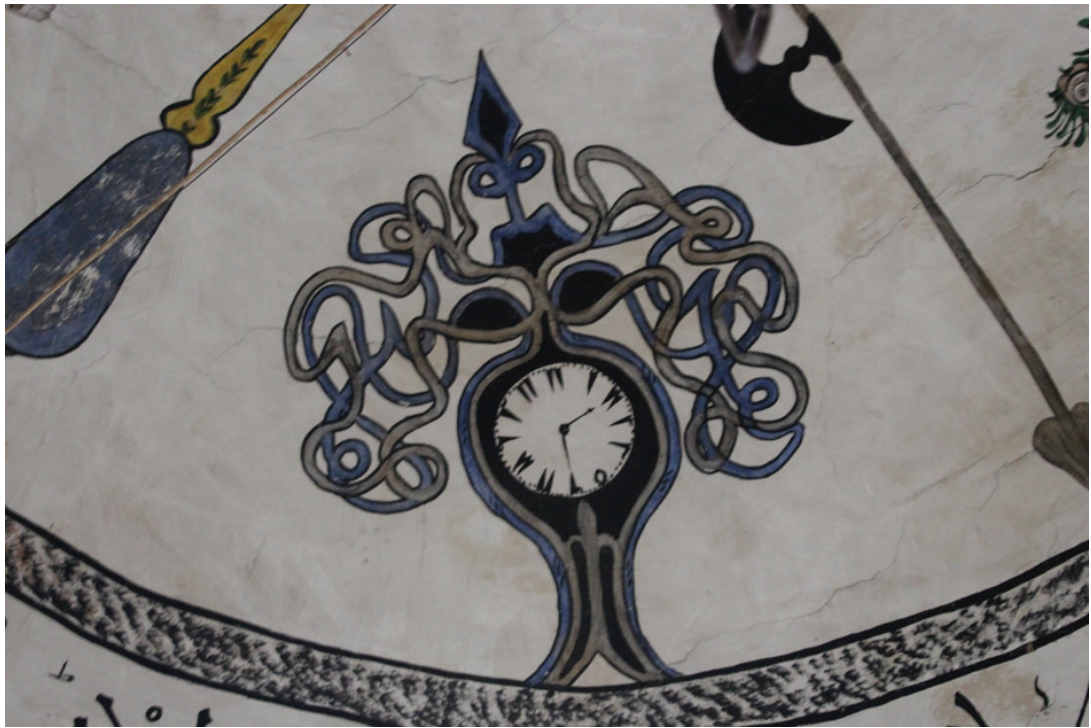

G. 15. Banaz Yeşilyurt Köyü Camii, bağdadi kubbe, saat tasviri (Şeyda Algaç, 2019)

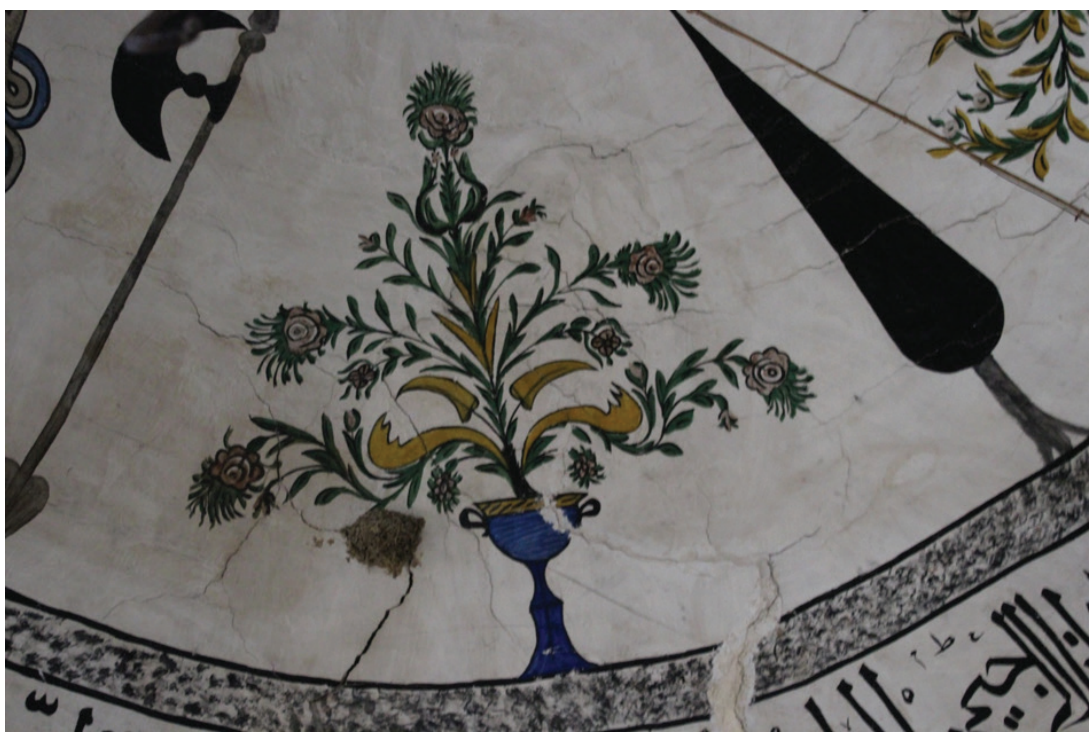

G. 16. Banaz Yeşilyurt Köyü camii, bağdadi kubbe, ayrıntı (Şeyda Algaç, 2019)

\section{Değerlendirme}

Yap1, mimari açıdan moloz taş ve ahşap malzemeyle inşa edilmiş, kuzeyde son cemaat yeri bulunan, minaresi kuzeybatıda yer alan, ana girişi kuzeyden ve mihrap ile aynı eksende, kuzey-güney doğrultusunda dikdörtgen planlı, Marsilya kiremit kaplı kırma çatılı, çatının altında beden duvarlarından içeriye alınmış, desteksiz ahşap bağdadi kubbesi olan bir yapı olarak değerlendirilebilir. 
Harim duvarlarından içeri alınmış ve ahşap çatı altına gizlenmiş bu tip bağdadi kubbeli yapılar Osmanlı mimarlığında sıklıkla kullanılmışlardır. Ev, köşk, saray gibi sivil mimari eserlerde 16. yüzyıl sonuyla 19. yüzyıl başları arasında oldukça yaygın olarak görülürler. ${ }^{8}$ Sivil mimari kökenli görünen bu tip kubbeler, özellikle İstanbul'da birtakım tarikat yapılarının veya mescit-tekke, cami-tekke türünden çift fonksiyonlu yapıların ayin mekânlarında da kullanılmıştır. ${ }^{9}$

Bağdadi kubbeler, coğrafi olarak Balkanlar'da ve tüm Anadolu'da görülmekle birlikte, en çok ahşap malzemenin bol ve ekonomik olduğu Karadeniz bölgesinde ${ }^{10}$ kullanılmıştır. Görülme sıklığı açısından Ege bölgesi ikinci sırada gelmektedir. Manisa-Kula Paşa Camii ${ }^{11}$ (1783- 84), Manisa-Soma Hızır Bey Camii ${ }^{12}$ (1791- 92), İzmirKaraburun Kösedere Köyü Camii1 ${ }^{13}$ (1814), İzmir-Karaburun, Eğlenhoca Köyü Camii ${ }^{14}$ (1823-24), Manisa-Kırkağaç Çiftehanlar Camiii ${ }^{15}$ (1864-65), İzmir-Kemalpaşa Yukarı Kızılca Köyü Halil Ağa Camiii ${ }^{16}$ (1893-94), Manisa-Turgutlu Irlamaz Köyü Camii ${ }^{17}$ (19. yüzyılın ikinci yarısı), Denizli-Akköy Yukarı Camii18 (19. yy. sonu 20. yy. başı) bu bölgenin batı kesiminde bulunan cami örnekleridir. Uşak ilinde de çok sayıda

7 Bağdadi: Ahşap iskelet yapılarda dikme aralarının sık aralıklı çıtalarla kaplanarak üstlerinin sıvanması tekniği. Bkz. Adnan Turani, Sanat Terimleri Sözlüğ̈̈ (Ankara: Toplum yayınevi, 1980), 18; Metin Sözen ve Uğur Tanyeli, Sanat Kavram ve Terimleri Sözlü̈̆̈̈ (İstanbul: Remzi Kitabevi, 1986), 33; Mustafa Şahin, "Giresun ve Trabzon İllerindeki Bağdadi Kubbeli Camiler” (Yüksek Lisans Tezi, Gazi Üniversitesi Sosyal Bilimler Enstitüsü, 2016), 15- 16.

8 M. Baha Tanman, "Beşiktaş Mevlevihanesi’ne İlişsin Bir Minyatürün Mimarlık ve Kültür Tarihi Açıısından Değerlendirilmesi," 17. Yüzyll Osmanlı Kültür ve Sanatı Sempozyum Bildirileri (19-20 Mart 1998 İstanbul) (İstanbul: Sanat Tarihi Derneği Yayınları, 1998), 196.

9 Tanman, "Beşiktaş Mevlevihanesi’ne İlişkin Bir Minyatürün Mimarlık ve Kültür Tarihi Açısından Değerlendirilmesi," 196- 197.

10 Samsun bölgesi örnekleri için bkz. E. Emine Naza-Dönmez, Wooden Mosques of the Samsun Region Turkey from the Past to the Present (Oxford: BAR International Series 1820, 2008), 144-145; Giresun ve Trabzon illeri için bkz. Şahin, "Giresun ve Trabzon İllerindeki Bağdadi Kubbeli Camiler," 252- 268; Merzifon ili için bkz. E. Emine Naza Dönmez, "Merzifon Hacı Hasan Camii Ahşap Kubbesi ve Süslemeleri," XII. Ortaçağ- Türk Dönemi Kazıları ve Sanat Tarihi Sempozyumu (15- 17 Ekim 2008 Çanakkale) Bildiriler (İzmir: Çanakkale Onsekiz Mart Üniversitesi Yayınları, 2010), 301-307; Amasya İli için bkz. Muzaffer Doğanbaş, “Özbaraklı Cami,” Arkitekt 67(2000), 60- 64, Meltem Daştan Özkan, “Amasya İli Yapılarındaki Kalem İşi Süslemeleri”, (Yüksek Lisans Tezi, Gazi Üniversitesi, 2001), 101-114, Neslihan Korkmaz, "Amasya Taşova İlçesi Özbaraklı Köyü Camileri,” Türk İslam Dünyası Sosyal Araștırmalar Dergisi 4/13 (2017), 385-408, erişim: 15 Aralık 2019, https://doi.org/10.16989/TIDSAD.1336.

11 Rüstem Bozer, Kula'da Türk Mimarisi (Ankara: Kültür Bakanlığı Yayınları, 1990), 47.

12 Rüçhan Arık, Batılllaşma Dönemi Türk Mimarisi Örneklerinden Anadolu'da Üç Ahşap Cami (Ankara: Ankara Üniversitesi Dil ve Tarih-Coğrafya Fakültesi Yayınları, 1973), 10-22.

13 Cengiz Gürbıyık, Karaburun Yarımadası'nda Türk Mimarisi (İzmir: Arkeoloji ve Sanat Yayınları, 2009), 42- 58.

14 Gürbıyık, Karaburun Yarımadası'nda Türk Mimarisi, 59-67.

15 İnci Kuyulu, “Kırkağaç Çiftehanlar Camii,” Arkeoloji- Sanat Tarihi Dergisi, V (1990), 103- 117.

16 Rahmi Hüseyin Ünal, "Yukarı Kızılca Köyü Halil Ağa Camii”, Sanat Tarihi Dergisi VI (1994), 211-225.

17 Cengiz Gürbıyık, “Turgutlu Irlamaz Köyü Camii”, CBÜ Sosyal Bilimler Dergisi 14/3 (2016), 146-162, erişim 15 Aralık 2019, https://doi.org/10.18026/cbusos.07482.

18 Kasım İnce, "Yukarı Camii/ Akköy-Denizli," Yüzüncü Yıl Üniversitesi Sosyal Bilimler Enstitüsü Dergisi 2 (2001), 65-79. Denizli ilindeki diğer örnekler için bkz. Nilgün Çevrimli, "Denizli ve Çevresinde Yer Alan Bazı Câmilerin Yapı Elemanlarının Değerlendirmesi,” Vakfflar Dergisi 47 (2017), 179-180. 
camide bağdadi kubbe kullanılmıştır. İl merkezinde Zincirli Camii ${ }^{19}$ (19. yy. sonu), Hacı Zeybek Camii ${ }^{20}$ (20. yy. baş1); il merkezi dışındaysa merkez Bozkuş Köyü Camiii $^{21}$ (1890- 91), merkez Aktaş Köyü Camiii ${ }^{22}$ Karahallı Kaykıllı Köyü Camii ${ }^{23}$ (191718) yerel örneklerdendir. ${ }^{24}$ Yeşilyurt köyü camiinde bulunan bağdadi kubbenin içi sıvanmış ve kalemişi bezemelerle doldurulmuştur. Bu açıdan Denizli Akköy Yukarı $\mathrm{Camii}^{25}$, Uşak Aktaş Köyü Camii ${ }^{26}$, Amasya-Merzifon Hacı Hasan Camii ${ }^{27}$ ve Amasya-Merzifon Taşova Özbaraklı Köyü camilerinde ${ }^{28}$ bulunan kalemişi bezemelerle doldurulmuş bağdadi kubbelere çok benzemektedir.

Yapıda, birçok dini mekânda görülebilecek bir yazı programı kullanılmışıtır. Her yapıda görülebilecek isimlere (İsm-i Celâl ve $\dot{I}_{s m-i}$ Nebi ile başlayan, dört halifeyle devam eden ve Hasan-Hüseyin ile nihayetlenen) Veysel Karani'nin ve Ashab-ı Kehf' in isimleri' ${ }^{29}$ eklenmiştir. Duvarlarda çeşitli dualardan bölümler vardır. Kuzey cephesinde kapının üzerinde yapının Allah'a itaat için yapıldığı belirtilirken dergâh kelimesi kullanılmıştır. Dergâh, Farsça kapı eşiği, sığınılacak yer, makam anlamlarına gelmekle beraber tarikatlara mensup şeyhlerle dervişlerin yaşadığı mekânlar için (tekke) anlamında da kullanılmaktadır. ${ }^{30}$ Mihrap duvarının batı bölümünün üstünde bulunan Hatip Mustafa Efendi ise kalem işlerinin uygulanmasından sorumlu kişi olsa gerektir.

Yapının kalemişlerinde yoğun olarak bitkisel motifler, servi ağaçları, vazolara yerleştirilmiş minyatür meyve ağaçları kullanılmıştır. Sarı meyvelerin limon, ayva ya da armut; kırmızı meyvelerinse elma ya da nar oldukları düşünülebilir. Batılılaşma döneminde vazolara ${ }^{31}$ yerleştirilmiş bitkisel bezemeler, minyatür ağaçlar iç mekânların

19 Kasım İnce, Uşak'ta Türk Mimarisi (Isparta: Fakülte Kitabevi, 2004), 42; Komisyon, UŞAK Kültürel Değerler Yapı Envanteri, 177.

20 İnce, Uş̧ak'ta Türk Mimarisi, 45; Komisyon, UŞAK Kültürel Değerler Yapı Envanteri, 168.

21 Komisyon, UŞAK Kültürel Değerler Yapı Envanteri, 179.

22 Türkan Acar, "Uşak İli Aktaş Köyü Camii," The Journal of Academic Social Science Studies 75 (2019), 361- 380, erişim 15 Aralık 2019, https://doi.org/10.9761 JASSS8014.

23 Komisyon, UŞAK Kültürel Değerler Yapı Envanteri, 192.

24 Uşak ilinde bulunan bağdadi kubbeli diğer örnekler için bkz. Acar, “Uşak İli Aktaş Köyü Camii,” 368-369, dipnot 12 ve dipnot 13 .

25 İnce, "Yukarı Camii/ Akköy-Denizli," 65- 79.

26 Acar, "Uşak İli Aktaş Köyü Camii," 377.

27 Dönmez, "Merzifon Hacı Hasan Camii Ahşap Kubbesi ve Süslemeleri," 301-307.

28 Doğanbaş, "Özbaraklı Cami," 60-64; Özkan, "Amasya İli Yapılarındaki Kalem İşi Süslemeleri," 101- 114; Korkmaz, “Amasya Taşova İlçesi Özbaraklı Köyü Camileri,” 385-408.

29 Malik Aksel, Türklerde Dini Resimler, Yay. Haz. Beşir Ayvazoğlu (İstanbul: Kapı Yayınları, 2010), 52-59.

30 Mehmet Zeki Pakalın, Osmanlı Tarih Deyimleri ve Terimleri Sözlüğü (İstanbul: Milli Eğitim Bakanlığı, 1993) 1: 425- 426; Süleyman Uludăg, Tasavvuf Terimleri Sözlü̈̆̈̈ (İstanbul: Kabalc1 Yayınevi, 2002), 102; Ethem Cebecioğlu, Tasavvuf Terimleri ve Deyimleri Sözlü̆̆̈̈, (İstanbul: Ağaç Kitabevi Yayınları, 2009), 158. İslam dünyasında tarikat yapılarının ortaya çıkmasını izleyen yüzyıllar boyunca, söz konusu kuruluşlar bazen bölge, devir, tarikat ve fonksiyon farklılıklarından, bazen de kullananın keyfi tercihinden dolayı çok çeşitli adlarla (asitane, dergâh, halvet, hankah, tekke, zaviye) anılmışlardır. Ahmet Işık Doğan, Osmanlı Mimarisinde Tarikat Yapılarl: Tekkeler, Zaviyeler ve Benzer Nitelikteki Fütüvvet Yapıları (İstanbul: İstanbul Teknik Üniversitesi Mühendislik Mimarlık Fakültesi Matbaas1, 1977), 58-97.

31 Azade Akar, “Tezyini San'atlarımızda Vazo Motifleri,” Vakıflar Dergisi 8 (1969), 267-271. 
duvarlarından önce kitap sanatlarında ortaya çıkmıştır. 17. yüzyılın ikinci yarısından sonra hazırlanan Gazneli Mahmud Albümü ${ }^{32}$ (İstanbul Üniversitesi Kütüphanesi T. 5461) manzara resimleri ile birlikte üzerinde çeşitli meyvelerle birlikte vazolara yerleştirilmiş buketlerin de bulunduğu renkli tasvirlere sahiptir. Natüralist üslupta çiçeklerin kitap sanatlarında kullanımıysa Kanuni Sultan Süleyman dönemine (15201566) kadar uzanmaktadır. ${ }^{33}$ Vazolara ve sepetlere yerleştirilmiş meyve ve bitkisel bezemelerin iç mekânlarda kullanımıysa en erken Topkapı Sarayı'nda III. Ahmed'in, 1705 tarihli Yemiş Odası'nda ${ }^{34}$ görülmektedir.

Güney duvarının orta bölümünde sıvaların altında bir ibrik motifi güçlükle seçilebilmektedir. İbrik motifi ${ }^{35}$, öncelikle ibadeti simgeleyebileceği gibi Hz. Muhammed (s.a.v) muhallefâtı içinde betimlenen ${ }^{36}$ ve ona ait olan ibrik de olabilir. Doğu duvarında sıvaların altından güçlükle görülebilen kent tasviri muhtemelen hayalî bir kent tasviridir. $^{37}$

Kubbede kullanılan motiflerden biri, rakamları Arap rakamlarıla Avrupai tarzda betimlenmiş saat tasviridir. Bu tip saatler sarkaçlı ya da sarkaçsız olarak Batılılaşma döneminde Balkanlar ve Anadolu'da sivil mekânlarda olduğu kadar dinî mekânlarda da sevilerek kullanılmıştır. ${ }^{38}$ Arnavutluk Tiran Ethem Bey Camii ${ }^{39}$ (kalemişleri: 1822/23), Arnavutluk Berat Bekârlar Camii ${ }^{40}$ (kalemişleri: 1827/28), İzmir Şadırvanaltı Camii Şadırvanı ${ }^{41}$ (kalemişleri: 1834), Tokat Zile Şeyh Nusret (Nasreddin) Ca-

32 Uğur Derman, "Benzeri Olmayan Bir Sanat Albümü: Gazneli Mahmud Mecmuası,” Türkiyemiz 14 (1974), 17-21; A. Süheyl Ünver ve Gülbün Mesara, Türk İnce Oyma Sanatı (Ankara: Türkiye İş Bankası Kültür Yayınları, 1980), 9-10; Yıldız Demiriz, Osmanlı Kitap Sanatında Naturalist Üslupta Çiçekler (İstanbul: İstanbul Üniversitesi Edebiyat Fakültesi, 1986), 267-277; Y1ldız Demiriz, “Tuhfe-i Gaznevi (Gazneli Mahmud Mecmuası)", P Sanat Kültür Antika Dergisi 13 (1999), 46-61.

33 Kanuni Sultan Süleyman döneminin başnakkaşı Karamemi, naturalist üslubu kitap tezhibinde kullanan ilk sanatçıdır. A. Süheyl Ünver, Müzehhip Karamemi (İstanbul: İstanbul Üniversitesi Yayınları), 1951.

34 Rüçhan Arık, Batılılaşma Dönemi Anadolu Tasvir Sanatı (Ankara: Kültür ve Turizm Bakanlığı Yayınları, 1988), 23; Mahmure Öz, "Topkapı Sarayı Yemiş Odası Üçyüz Yıldır Solmayan Çiçekler,” Z Kültür/ Sanat/ Şehir Bitki Ressamlı̆gl 1 (2017), 178-181.

35 İbrik motifinin ikonografisi için bkz. Semiha Altıer, “Osmanlı Sanatı'nda İbrik Tasvirleri ve İkonografisi,” Çanakkale Araştırmaları Türk Ylllığ, 17/26 (2019), 149-202 erişim 15 Aralık 2019, https://doi.org/10.17518/ canakkalearastirmalari.585358; Ülkü Küçükkurt, "Türk Kültüründe İbrik ve İbrik Motifinin Geleneksel Sanatlara Yansıması," Euroasia Journal of Social Sciences \& Humanities 7 (2019), 139-151.

36 Şeyda Algaç, "Afyonkarahisar Başmakçı Hilal (Cuma) Camii ve Kalemişi Bezemeleri, VIII. Uluslararası Afyonkarahisar Araştırmaları Sempozyumu (5- 7 Nisan 2018 Afyonkarahisar) Bildiri Kitabı (Afyonkarahisar: Afyonkarahisar Belediyesi, 2019), 277.

37 Arık, Batılllaşma Dönemi Anadolu Tasvir Sanatı, 122-125.

38 Mustafa Çetinaslan ve Ahmet Yavuzyılmaz, "Türk Süsleme Sanatlarında Saat Motifleri," Uluslararası İslam Medeniyetinde Zaman Sempozyumu (8- 11 Ekim 2015 Konya) Bildiriler II (İstanbul: Selçuklu Belediyesi, 2016) 323-328.

39 Ruhi Konak ve Metin Uçar, "Tiran Ethem Bey Camisi Harim Duvarlarında Yer Alan Minyatür Üsluplu Resimler," Uşak Üniversitesi Sosyal Bilimler Dergisi, 8/ 3 (2015), 3.

40 Metin Uçar, "Berat Bekârlar Camii Duvar Resimleri," The Journal of Academic Social Science Studies (JASSS) 6/7 (2013), 1163, erişim 15 Aralık 2019, http://dx.doi.org/10.9761/JASSS1715.

41 Arık, Batılılaşma Dönemi Anadolu Tasvir Sanatı, 49; Günsel Renda, Batılllaşma Döneminde Türk Resim Sanatı 1700- 1850 (Ankara: Hacettepe Üniversitesi Yayınları, 1977), 145. 
mii- Türbesi ${ }^{42}$ (kalemişleri: 1858), Amasya II. Bayezid Camii Şadırvanı ${ }^{43}$ (kalemişleri: 1872), Samsun Kavak Bekdemir Köyü Camii ${ }^{44}$ (kalemişleri: 1876), Konya Doğanhisar Deştiğin Ulu Camii ${ }^{45}$ (kalemişleri: 1879), Dazkırı İdris Köyü Cami ${ }^{46}$ (kalemişleri: 1901), Başmakçı Hilâl Camii ${ }^{47}$ (kalemişleri: 19. yy), Kırşehir Mucur Emine Hatun Camii $^{48}$ (kalemişleri: 19. yy), Giresun Yağlidere Tekke Köyü Camii ${ }^{49}$ (kalemişleri: 19. yy), Çorum Mecitözü Alören Köyü Camii ${ }^{50}$ (kalemişleri: 19. yüzyıl sonları), Uşak Aktaş Köyü Camii ${ }^{51}$ (kalemişleri: 19. yüzyılın son çeyreği) saat tasvirine sahip camilerden bazılarıdır. Saat, Batı'dan Osmanlı dünyasına gelen teknik bir yeniliktir ve yaygınlaşmaya başlaması saate meraklı bir Sultan olan III. Selim (1789-1807) ile olmuştur. ${ }^{52}$ J. Pardoe, II. Mahmud döneminde Türk evlerinde Fransız saatlerinin kullanıldığını söyler. ${ }^{53}$ Saat, Batılılaşmanın simge eşyalarındandır ve Tanzimat alafrangall$\breve{g} ı n \imath$ temsil eder. ${ }^{54}$ Ayrıca İslam medeniyetinde zamanın bilincine varmak Ibn 'ül - vakt olmak önemlidir. Dinî mekânlarda kullanılan saat tasviri, ibadet edenlere, zamanın gelip geçtiğini, bunun bilincinde olunması gerektiğini hatırlatmaktadır.

Kubbenin içinde kullanılan teber ${ }^{55}$ ve keşkül ${ }^{56}$ betimlemeleri, seyyah dervişlerle ${ }^{57}$

42 Halit Çal, "Şeyh Nasreddin (Nusret) Türbesi," Türk Tarihinde Tokat Sempozyumu (2- 6 Temmuz 1986 Tokat) (Ankara: Gelişim Matbaası, 1987), 427.

43 Günsel Renda, "II. Bayezid Külliyesinde Muvakkithane," İstanbul Üniversitesi Edebiyat Fakültesi Sanat Tarihi Yıllı̆̆l VI (1976), 190; Arık, Batılllaşma Dönemi Anadolu Tasvir Sanatı, 84.

44 Dönmez, Wooden Mosques of the Samsun Region Turkey from the Past to the Present, 32- 42.

45 Haşim Karpuz, Türk Kültür Varlıkları Envanteri 42, (Ankara: Türk Tarih Kurumu, 2009) 2: 1733-1736.

46 Şeyda Algaç, "Afyonkarahisar Dazkır1-İdris Köyü Camii ve Kalemişi Bezemeleri,” Yüzüncü Yıl Üniversitesi Sosyal Bilimler Enstitüsü Dergisi 1/ 2 (2017), 423.

47 Şeyda Algaç, "Afyonkarahisar Başmakçı Hilal (Cuma) Camii ve Kalemişi Bezemeleri,” 275.

48 Şerife Tali, "Kırșehir/ Mucur’daki Hüseyin Ağa Camii ile Emine Hanım Camii’nin Kalemişleri," Uluslararası Sosyal Araştırmalar Dergisi 6/25 (2013), 508.

49 Şerife Tali, "Giresun Yağlıdere Tekke Köyü Camii Kalem İși Bezemeleri," Uluslararası Sosyal Araştırmalar Dergisi 7/31 (2014), 490.

50 Murat Çerkez, “Mecitözü’nde Mütevazı Bir Külliye: Alören Köyü Külliyesi,” History Studies, 11/2 (2019), 501, erişim: 15 Aralık 2019, https://doi.org/10.9737/hist.2019.728.

51 Acar, "Uşak İli Aktaş Köyü Camii," 374.

52 Tolga Uzun, "19. Yüzyıl Osmanlı Duvar Resimlerinde Yeniliğin ve Değişimin Sembolü Tasvirler,” XX. Uluslararası Ortaçağ Türk Dönemi Kazıları ve Sanat Tarihi Araştırmaları Sempozyumu (02- 05 Kasım 2016 Sakarya) Sempozyum Kitabı II (Sakarya: Sakarya Üniversitesi Yayınları 2017), 853.

53 Renda, Batılılaşma Döneminde Türk Resim Sanatı (1700-1850), 24, dipnot 46.

54 Tarkan Okçuoğlu, "18. ve 19. Yüzyıllarda Osmanlı Duvar Resimlerinde Betimleme Anlayışı” (Doktora Tezi, İstanbul Üniversitesi, 2000), 44.

55 Teber, Farsça balta demektir. Demir yahut ağaç bir çubuk üzerine genişliğine takılmış bir tarafı ay şeklinde, öbür tarafı sivri yahut iki tarafı ay şeklinde, bazılarının da ayların uçları kesik olmak üzere muhtelif tarzlarda yapılırlardı. Pakalın, Osmanlı Tarih Deyimleri Sözlüğ̈̈, 3: 429; Atasoy, Derviş Çeyizi Türkiye'de Tarikat Giyim- Kuşam Tarihi, 273-274; Cebecioğlu, Tasavvuf Terimleri ve Deyimleri Sözlüğ̈̈, 637.

56 Keşkül, dervişler ve dilenciler tarafından kullanılan Hindistan cevizi, abanoz ya da metalden yapılmış, iki ucundan zincirle bağlanmış olan çanak. Pakalın, Osmanlı Tarih Deyimleri Sözlüğü, 2:251; Atasoy, Derviş Çeyizi Türkiye'de Tarikat Giyim-Kuşam Tarihi, 256-260; Uludağ, Tasavvuf Terimleri Sözlüğü, 211; Cebecioğlu, Tasavvuf Terimleri ve Deyimleri Sözlüğü, 368.

57 Ekrem Işın ve Selahattin Özpalabıyıklar, "Hoş Gör Ya Hu” Osmanlı Kültüründe Mistik Semboller Nesneler, (İstanbul: Yapı Kredi Yayınları, 1999), 73, 77. 
ilgili tekke sembolleridir. Bu tip semboller genellikle Bektaşilik ${ }^{58}$, Rufailik ${ }^{59}$, Kalenderilik $^{60}$ ve Kalenderiliğin 14. yüzyıl Anadolusu'ndaki türevi olan Rum Abdallarr ${ }^{61}$ ile ilişkilendirilir. Rum Abdalları yoluyla Kalenderi kökenli bu eşyalar Bektaşî ve Rufaî tarikatlarına da girmiş, geç dönemin ürünü olan bazı Bektaşî ve Rufaî armalarında da yer almıştır. ${ }^{62}$ Tekke sembolleri mimari bezemede en erken 1734/ 1735 tarihinde tamamlanmış olan İstanbul Hekimoğlu Ali Paşa Külliyesi'nde bulunan caminin mihrabında görülür. Burada mihrabın üst kısmında Kadirî-Eşrefî tacı ve Kadirî gülü kabartmaları kullanılmıştır. ${ }^{63} \mathrm{Bu}$ tip amblematik tekke sembollerinin mimaride kullanımı II. Mahmud döneminden itibaren yoğunlaşır. Neden olarak Sultan Abdülmecid devrinde (1839- 1861) Tanzimat ile birlikte son şeklini alan Osmanlı armasının toplumda yarattığı moda olduğu söylenebilir. ${ }^{64}$ Tekke kültürüne ait eşya betimlemeleri özellikle Orta Karadeniz bölgesinde birçok dinî yapıda görülür. Merzifon Kara Mustafa Paşa Camii şadırvanının kubbesi ${ }^{65}$ (kalemişleri: 1875), Tokat Zile Yeşilce Köyü Şeyh Eylük Türbesi $^{66}$ (kalem işleri: 19. yüzyılın 2. yarıs1), Amasya Gümüşhacıköy Ali Pir Civan (kalem işleri: 1902) ve Hacı Nazır Baba (Ahmet Çelebi) (kalem işleri: 19. yüzyıl sonu) Türbeleri67 ${ }^{67}$, Merzifon Piri Baba Türbesi ${ }^{68}$ (kalemişleri: 1904) benzer örneklerin görülebileceği yapılardır. Ege Bölgesinde de birçok yapıda özellikle köy camilerinde bu tip sembollere rastlanabilir. Aydın Kuyucak Kayran Köyü Camii ${ }^{69}$ (Kalemişleri: 19. yüzyıl ortası), Denizli Baklan Boğaziçi Kasabası Eski Camii (Kalemişleri: 1876) ${ }^{70}$, Denizli

58 Hamit Zübeyr Koşay, "Bektaşilik ve Hacı Bektaş Tekkesi," Türk Etnografya Dergisi X (1967), 24-25.

59 M. Baha Tanman, "İstanbul Tekkelerinin Mimari ve Süsleme Özellikleri Tipolojisi Denemeleri” (Doktora Tezi, İstanbul Üniversitesi, 1990), 1: 145.

60 Tanman, "İstanbul Tekkelerinin Mimari ve Süsleme Özellikleri Tipolojisi Denemeleri," 1: 95.

61 M. Baha Tanman, "Merzifon, Kara Mustafa Paşa Camii Şadırvanının Kubbesinde Zileli Emin'in Yarattığı "Osmanlı Dünyası" ve Bu Dünyaya Yansıyan Kişiliği," Sanat Tarihinde İkonografik Araştırmalar Güner İnal'a Armağan (Ankara: Hacettepe Üniversitesi Edebiyat Fakültesi, 1993), 495-496.

62 Tanman, "Merzifon, Kara Mustafa Paşa Camii Şadırvanının Kubbesinde Zileli Emin'in Yarattığı "Osmanlı Dünyası" ve Bu Dünyaya Yansıyan Kişiliği," 498.

63 M. Baha Tanman, "Hekimoğlu Ali Paşa Camii’ne İlişkin Bazı Gözlemler," Oktay Aslanapa Armağanı (İstanbul: Bağlam Yayıncılık, 1996), 258.

64 Tanman, "İstanbul Tekkelerinin Mimari ve Süsleme Özellikleri Tipolojisi Denemeleri," 1:380- 381.

65 Rüçhan Arık, “Anadolu’da Bir Halk Ressamı: Zileli Emin,” Türkiyemiz 16 (1975), 8-13; M. Baha Tanman, "Merzifon, Kara Mustafa Paşa Camii Şadırvanının Kubbesinde Zileli Emin'in Yarattığı "Osmanlı Dünyası" ve Bu Dünyaya Yansıyan Kişiliği,” 498; Okçuoğlu, “18. ve 19. Yüzyıllarda Osmanlı Duvar Resimlerinde Betimleme Anlayışı," 141-143.

66 Halit Çal, “Tokat Zile Yeşilce Köyü Şeyh Eylük Türbesi,” Prof. Dr. Yılmaz Önge Armağanı (Konya: Selçuk Üniversitesi Araştırma Merkezi, 1993), 294.

67 Savaş Yıldırım, “Amasya Gümüşhacıköy Türbelerindeki Kalem İşi Süslemeler”, Art Sanat 10 (2018), 297, 306, erişim: 15 Aralık 2019, https://doi.org/10.26650/artsanat.2018.10.0013.

68 Muzaffer Doğanbaş, “Amasya Yöresi Alevi Ziyaretgâhları,” Türk Kültürü ve Hacı Bektaş Veli Araştırma Dergisi 17(2001), 105-113; Harun Yıldız, "Amasya Yöresi Örneğinde Alevi/Bektaşi Kültüründe İnanç Merkezleri," Uluslararast Sosyal Araştırmalar Dergisi, 4/16 (2011), 471-480.

69 Erbil Cömertler Aktuğ ve Kadir Pektaş, “Geç Dönem Kalem İşi Süslemeli Bir Eser: Aydın Kuyucak Kayran Köyü Camii," Medeniyet Sanat, IMÜ Sanat, Tasartm ve Mimarlı Fakültesi Dergisi, $2 / 2$ (2016), 14.

70 Şakir Çakmak, "Boğaziçi Kasabası Eski Cami (Baklan/ Denizli)," 9. Milletlerarası Türk Sanatları Kongresi (23-27 Eylül 1991 İstanbul) Bildiriler I (Ankara: Kültür Bakanlığı, 1995), 534. 
Güney Belenardıç (Torapan) Köyü Camii ${ }^{71}$ (Kalemişleri: 1885/86), Afyonkarahisar Başmakçı Recep Bey Camii ${ }^{72}$ (Kalemişleri: 1892), bu tip tekke sembollerinin kullanıldığı camilerden bazılarıdır. Uşak ilinde ise Uşak Ulu Caminin mihrabının üstünde bulunan kalemişi bezemelerde, bir adet iki yüzlü teber, muhtemelen Kadirilere ait iki adet müjganlı tac-1 şerif ve bir adet mütteka betimlemesi bulunmaktadır. M. Baha Tanman'a göre;

"Bu tip öğeler, herhangi bir süsleme öğesinden farklı olarak, bulundukları yeri süsleyerek daha cazip kılmak amacıyla tasarlanmamış, her ne kadar tezyinî bir yönleri olsa da aslında yapıyı kullanan kişilere ortak değerlerini, kavramlarını hatırlatmak, tekkenin hangi tarikata bağlı olduğunu belirtmek, kısacası süslemekten ziyade "bir şeylere işaret etmek" için düşünülmüşlerdir."’3

Uşak ili, kalemişlerinin kullanıldığı yapılar açısından çok zengin değildir. Kent merkezindeki yapılarda görülen kalemişi bezemeler günümüze yakın dönemlerde yapılmışlardır. ${ }^{74}$ Merkez dişındaki köy camilerindense Sivaslı ilçesindeki Akarca Köyü camisinde ${ }^{75}$ ve Aktaş Köyü camisinde ${ }^{76}$ kalemişi bezemeler bulunmaktadır. Bu örneklerle karşılaştırıldığında Yeşilyurt köyü camiinin kalemişi bezemeleri, Uşak il sınırları içinde benzersiz tek örnek olarak kalmaktadır. Uşak il sınırları dışında da tasvirli köy camileri içinde kullanılan bezeme üslubu açısından bir benzeri bulunmamaktadır.

\section{Sonuç}

18. yüzyılın ilk çeyreğinde 28. Çelebi'nin Fransa seyahatiyle başlayan Batılılaşma hareketi, Osmanlı medeniyetinin siyasi, idari, askeri yapısında, kültürel ve sanatsal üretim anlayışında, mimaride ve mimariye bağlı gelişen iç mekân dekorasyonunda önemli değişiklikler yaratır. 18. yüzyılın sonlarına doğru bu değişim, imparatorluğun diğer bölgelerine Balkanlar'a ve Anadolu'ya yayılır. 19. yüzyıl boyunca Anadolu'nun hemen hemen her bölgesinde iç mekânları Avrupa etkili barok süsler, yeni natüralist anlayışla bezenmiş dinî ve sivil mimari örnekleri görülür. Ancak Orta Karadeniz ve Ege bölgelerinde bu yapılar yoğunluk gösterir. Ege bölgesinin iç kısımlarında Denizli ve Afyonkarahisar'da çok sayıda nakışlı ve tasvirli cami olmasına rağmen Uşak’ta bu sayı oldukça azdır.

71 Şakir Çakmak, "Belenardıç (Torapan) Köyü Camii (Güney/Denizli)," Sanat Tarihi Dergisi VII (1994), 23.

72 Ertan Daş, "Başmakçı (Afyon) Recep Bey Camii," 2. Afyonkarahisar Araştırmaları Sempozyumu Bildirileri (3- 4 Mayls 1991 Afyon) (Afyon: Afyon Belediyesi Yayınları, 1991), 127.

73 Tanman, "İstanbul Tekkelerinin Mimari ve Süsleme Özellikleri Tipolojisi Denemeleri," I: 379- 380.

74 İnce, Uş̧ak'ta Türk Mimarisi, 134; Elif Gürsoy, "Uşak’ta Perde Motifli Mihraplar," Akademik Sosyal Araşttrmalar Dergisi 3/10 (2015), 146-157.

75 Elif Gürsoy, “Uşak İli Sivaslı İlçesi Akarca Köyü Camisi,” Elektronik Sosyal Bilimler Dergisi 16/62 (2017), 1001-1014, erişim: 15 Aralık 2019, https://doi.org/10.17755/esosder.329109.

76 Acar, “Uşak İli Aktaş Köyü Camii,” 372-377. 
Banaz Yeşilyurt köyü camii, mimari açıdan moloz taş ve ahşapla inşa edilmiş, kuzeyde son cemaat yeri bulunan, minaresi kuzeybatıda yer alan, ana girişi kuzeyden ve mihrap ile aynı eksende olan, kuzey- güney yönlü, dikdörtgen planlı, Marsilya kiremit kaplı kırma çatılı, çatının altında beden duvarlarından içeriye alınmış, desteksiz ahşap bağdadi kubbesiyle yerel mimarlığın bir ürünüdür. Ancak kalemişleri açısından özgündür. Kalemişlerinde kullanılan natüralist bitkiler, 18. yüzyılın ilk yıllarından itibaren iç mekânlarda görülmelerine rağmen Avrupaî tarzda yapılmış, rakamları Arap rakamlarıyla belirlenmiş saat, 19. yüzyılın ilk çeyreğinde Balkan örneklerinde görülmeye başlar ve 19. yüzyılın ikinci yarısından sonra Anadolu'ya yayılır. Tekke sembollerinin iç mekânlarda kullanımıysa erken tarihli birkaç örnek dışında 19. yüzyılın ikici yarısından sonra yaygınlık kazanır. Yapının inşa kitabesi olmamasına rağmen kalemişlerinde kullanılan motifler ve doğu duvarındaki 1318 (1900/1901)'den 1325 (1907/1908)'e kadar sırayla yazılmış yıllar göz önüne alınarak yapının kalemişılerinin 19. yüzyılın sonlarına doğru yapıldığı söylenebilir. Kalemişlerinden sorumlu olan kişiyse güney duvarının batı kısmında adı belirtilen Hatip Mustafa Efendi olmalıdır. Yapı ise kalemişlerinden bir müddet önce inşa edilmiş olmalıdır.

Kubbede kullanılan tekke sembolleri, kuzey cephesindeki kapının üzerinde bulunan "dergâh" ifadesi, yapının yazı programı ve çatı altına gizlenmiş bağdadi kubbe ile birlikte değerlendirilerek yapının, tekkelerin kapatılma tarihi olan 1925 senesi öncesinde cami işlevinin yanında tevhidhâne gibi ikinci bir işlevi daha olduğunu düşünülebilir.

Yap1, bir köy camisi olarak sıra dışı özelliklere sahiptir. En kısa sürede aslına uygun olarak restore edilmeli ve gelecek kuşaklara aktarılmalıdır. Restorasyon sonrasında elde edilecek yeni bulguların ışığında yapı tekrar değerlendirilmelidir.

Hakem Değerlendirmesi: Dış bağımsız.

Çıkar Çatışması: Yazar çıkar çatışması bildirmemiştir.

Finansal Destek: Yazar bu çalışma için finansal destek almadığını beyan etmiştir.

Peer-review: Externally peer-reviewed.

Conflict of Interest: The author has no conflict of interest to declare.

Grant Support: The author declared that this study has received no financial support.

\section{Kaynakça/References}

Acar, Türkan. "Uşak İli Aktaş Köyü Camii.” The Journal of Academic Social Science Studies 75 (2019): 361-380. Erişim 15 Aralık 2019, https://doi.org/10.9761/JASSS8014.

Akar, Azade. “Tezyini San'atlarımızda Vazo Motifleri.” Vakıflar Dergisi 8 (1969): 267-271.

Aksel, Malik. Türklerde Dini Resimler. Haz. Beşir Ayvazoğlu. İstanbul: Kapı Yayınları, 2010.

Aktuğ, Cömertler Erbil ve Kadir Pektaş. “Geç Dönem Kalem İşi Süslemeli Bir Eser: Aydın Kuyucak

Kayran Köyü Camii.” Medeniyet Sanat, IMÜ Sanat, Tasarım ve Mimarlık Fakültesi Dergisi 2/2 (2016): 9-25. 
Algaç, Şeyda. "Afyonkarahisar Dazkırı-İdris Köyü Camii ve Kalemişi Bezemeleri.” Yüzüncü Yıl Üniversitesi Sosyal Bilimler Enstitüsü Dergisi 1/2(2017): 421-432.

Algaç, Şeyda. "Afyonkarahisar Başmakçı Hilal (Cuma) Camii ve Kalemişi Bezemeleri." VIII. Uluslararası Afyonkarahisar Araştırmaları Sempozyumu (5-7 Nisan 2018 Afyon) Bildiri Kitabı. Afyonkarahisar: Afyonkarahisar Belediyesi, 2019, 272-280.

Altıer, Semiha. "Osmanlı Sanatı'nda İbrik Tasvirleri ve İkonografisi." Çanakkale Araştırmaları Türk Yıllı̆̆ı 17/26 (2019): 149-202. Erişim 15 Aralık 2019, https://doi.org/10.17518/canakkalearastirmalari.585358.

Arık, Rüçhan. Batılılaşma Dönemi Türk Mimarisi Örneklerinden Anadolu'da ÜÇ Ahşap Cami. Ankara: Ankara Üniversitesi Dil ve Tarih-Coğrafya Fakültesi Yayınları, 1973.

Arık, Rüçhan. “Anadolu' da Bir Halk Ressamı: Zileli Emin.” Türkiyemiz 16 (1975): 8- 13.

Arık, Rüçhan. Batılılaşma Dönemi Anadolu Tasvir Sanatı. Ankara: Kültür ve Turizm Bakanlığı Yayınları, 1988.

Atasoy, Nurhan. Derviş Çeyizi Türkiye'de Tarikat Giyim-Kuşam Tarihi. İstanbul: Kültür Bakanlığı Yayınları, 2000.

Bozer, Rüstem. Kula'da Türk Mimarisi. Ankara: Kültür Bakanlığı Yayınları, 1990.

Cebecioğlu, Ethem. Tasavvuf Terimleri ve Deyimleri Sözlüğ̈̈. İstanbul: Ağaç Kitabevi Yayınları, 2009.

Çakmak, Şakir. “Belenardıç (Torapan) Köyü Camii (Güney/ Denizli).” Sanat Tarihi Dergisi 7 (1994): 19-26.

Çakmak, Şakir. "Boğaziçi Kasabası Eski Cami (Baklan/ Denizli).” 9. Milletlerarası Türk Sanatları Kongresi (23-27 Eylül 1991 İstanbul) Bildiriler I. Ankara: Kültür Bakanlığı, 1995, 529-540.

Çal, Halit. "Şeyh Nasreddin (Nusret) Türbesi.” Türk Tarihinde ve Kültüründe Tokat Sempozyumu (2- 6 Temmuz 1986 Tokat). Ankara: Gelişim Matbaası, 1987, 427-461.

Çal, Halit. “Tokat Zile Yeşilce Köyü Şeyh Eylük Türbesi.” Prof. Dr. Yılmaz Önge Armağanı. Konya: Selçuk Üniversitesi Araştırma Merkezi, 1993, 293-306.

Çerkez, Murat. “Mecitözü’nde Mütevazı Bir Külliye: Alören Köyü Külliyesi. History Studies 11/2 (2019): 495-533. Erişim 15 Aralık 2019, https://doi.org/10.9737/hist.2019.728.

Çetinaslan, Mustafa ve Ahmet Yavuzyılmaz. "Türk Süsleme Sanatlarında Saat Motifleri." Uluslararası İslam Medeniyetinde Zaman Sempozyumu (8-11 Ekim 2015 Konya) II. İstanbul: Selçuklu Belediyesi, 2016, 321-337.

Çevrimli, Nilgün. "Denizli ve Çevresinde Yer Alan Bazı Câmilerin Yapı Elemanlarının Değerlendirmesi." Vakıflar Dergisi 47 (2017): 169-204.

Dahiliye Vekaleti. Köylerimiz. İstanbul: Matbaacılık ve Neșriyat Türk Anonim Șirketi, 1933.

Daş, Ertan. "Başmakcı (Afyon) Recep Bey Camii." II. Afyonkarahisar Araştırmaları Sempozyumu Bildirileri (3-4 Mayıs 1991 Afyon), Afyon: Afyon Belediyesi Yayınları, 1991, 119-132.

Demiriz, Yıldız. Osmanlı Kitap Sanatında Naturalist Üslupta Çiçekler. İstanbul: İstanbul Üniversitesi Edebiyat Fakültesi, 1986.

Demiriz, Yıldız. "On Yedinci Yüzyıl Sonlarından Bir Çiçekli Süsleme Çeşitlemesi Tuhfe- i Gaznevi Gazneli Mahmud Mecmuası.” P Sanat Kültür Antika 13 (1999): 46-61.

Demiriz, Yıldız. Osmanlı Kitap Sanatında Doğal Çiçekler. İstanbul: Yorum Sanat, 2005.

Derman, Uğur. "Benzeri Olmayan Bir Sanat Albümü: Gazneli Mahmud Mecmuası.” Türkiyemiz 14 (1974): 17-21. 
Doğan, Ahmet Işık. Osmanlı Mimarisinde Tarikat Yapıları Tekkeler, Zaviyeler ve Benzer Nitelikteki Fütüvvet Yapıları. İstanbul: İstanbul Teknik Üniversitesi Mühendislik Mimarlık fakültesi Matbaas1, 1977.

Doğanbaş, Muzaffer. “Amasya Yöresi Alevi Ziyaretgâhlar1.” Türk Kültürü ve Hacı Bektaş Veli Araştırma Dergisi 17 (2001): 105-113.

Doğanbaş, Muzaffer. “Özbaraklı Cami.” Arkitekt 67/473 (2000): 60-64.

Dönmez, Naza E. Emine. Wooden Mosques of the Samsun Region, Turkey from the Past to the Present. Oxford: BAR International Series 1820, 2008.

Dönmez, Naza E. Emine. "Merzifon Hacı Hasan Camii Ahşap Kubbesi ve Süslemeleri." XII. Ortaçağ-Türk Dönemi Kazıları ve Sanat Tarihi Sempozyumu (15-17 Ekim 2008 Çanakkale), İzmir: Çanakkale Onsekiz Mart Üniversitesi Yayınları, 2010, 301-307.

Gürbıyı, Cengiz. Karaburun Yarımadası'nda Türk Mimarisi. İzmir: Arkeoloji ve Sanat Yayınları, 2009. Erişim 15 Aralık 2019, https://doi.org/10.18026/cbusos.07482.

Gürbıyık, Cengiz. “Turgutlu Irlamaz Köyü Camii.” Celal Bayar Üniversitesi Sosyal Bilimler Dergisi 14/3 (2016): 146-162.

Gürsoy, Elif. “Uşak’ta Perde Motifli Mihraplar.” Akademik Sosyal Araştırmalar Dergisi 3/10 (2015): 146-157.

Gürsoy, Elif. “Uşak İli Sivaslı İlçesi Akarca Köyü Camisi.” Elektronik Sosyal Bilimler Dergisi 16/62 (2017): 1001-1014. Erişim: 15 Aralık 2019, https://doi.org/10.17755/esosder.329109.

Işı1n, Ekrem ve Selahattin Özpalabıyıklar. "HOŞ GÖR YÂ HÛ”' Osmanlı Kültüründe Mistik Semboller Nesneler. İstanbul: Yap1 Kredi Yayınları, 1999.

İnce, Kasım. “Denizli Akköy Yukarı Cami.” Van Yüzüncü Yıl Üniversitesi Sosyal Bilimler Enstitüsü Dergisi 2 (2001): 65-79.

İnce, Kasım. Uşak'ta Türk Mimarisi. Isparta: Fakülte Kitabevi, 2004.

Karpuz, Haşim. Türk Kültür Varlıkları Envanteri 42. 3 Cilt. Ankara: Türk Tarih Kurumu, 2009.

Komisyon. UŞAK Kültürel Değerler Yapı Envanteri. İzmir: Uşak Valiliği İl Kültür Turizm Müdürlüğü, 2007.

Konak, Ruhi ve Metin Uçar. "Tiran Ethem Bey Camisi Harim Duvarlarında Yer Alan Minyatür Üsluplu Resimler.” Uş̧ak Üniversitesi Sosyal Bilimler Dergisi 8/3 (2015): 1-20.

Korkmaz, Neslihan. “Amasya Taşova İlçesi Özbaraklı Köyü Camileri.” Türk İslam Dünyası Sosyal Araştırmalar Dergisi 4/13 (2017): 385-408. Erişim 15 Aralık 2019, https://doi.org/10. 16989/ TIDSAD.1336.

Koşay, Hamit Zübeyr. "Bektaşilik ve Hacı Bektaş Tekkesi.” Türk Etnografya Dergisi 10 (1967): $19-26$.

Kuyulu, İnci. “Kırkağaç Çiftehanlar Camii.” Arkeoloji-Sanat Tarihi Dergisi V (1990): 103-117.

Küçükkurt, Ülkü. “Türk Kültüründe İbrik ve İbrik Motifinin Geleneksel Sanatlara Yansıması.” Euroasia Journal of Social Sciences \& Humanities 7 (2019): 139-151.

Okçuoğlu, Tarkan. “18. ve 19. Yüzyıllarda Osmanlı Duvar Resimlerinde Betimleme Anlayışı.” Doktora Tezi, İstanbul Üniversitesi, 2000.

Öntuğ, Mustafa Murat. “Osmanlı'dan Cumhuriyete Banaz.” Afyon Kocatepe Üniversitesi Sosyal Bilimler Dergisi 3/2 (2001): 41-55. 
Öz, Mamure. “Topkapı Sarayı Yemiş Odası Üçyüz Yıldır Solmayan Çiçekler.” Z Kültür/ Sanat/Şehir Bitki Ressamlığı 1 (2017): 178-181.

Özdeğer, Mehtap. 15- 16. Yüzyıl Arşiv Kaynaklarına Göre Uşak Kazasının Sosyal ve Ekonomik Tarihi. İstanbul: Filiz Kitabevi, 2001.

Özkan, Daştan Meltem. “Amasya İli Yapılarındaki Kalem İşi Süslemeleri.” Yüksek Lisans Tezi, Gazi Üniversitesi, 2001.

Pakalın, Mehmet Zeki. Osmanlı Tarih Deyimleri ve Terimleri Sözlüğ̈̈. 3 cilt. İstanbul: Milli Eğitim Bakanlı̆̆1, 1993.

Renda, Günsel. “II. Bayezid Külliyesinde Muvakkithane.” İstanbul Üniversitesi Edebiyat Fakültesi Sanat Tarihi Yıllı̆̆l VI (1976): 181-206.

Renda, Günsel. Batılılaşma Döneminde Türk Resim Sanatı (1700- 1850). Ankara: Hacettepe Üniversitesi yayınları, 1977.

Sözen, Metin ve Uğur Tanyeli. Sanat Kavram ve Terimleri Sözlüğü. İstanbul: Remzi Kitabevi, 1986.

Şahin, Mustafa. “Giresun ve Trabzon İllerindeki Bağdadi Kubbeli Camiler.” Yüksek Lisans Tezi, Gazi Üniversitesi, 2016.

Tali, Şerife. "Kırşehir/Mucur'daki Hüseyin Ağa Camii İle Emine Hanım Camii’nin Kalemişleri." Uluslararası Sosyal Araştırmalar Dergisi. C. 6. 25:504-528.

Tali, Şerife. "Giresun Yağlıdere Tekke Köyü Camii Kalem İşi Bezemeleri.” Uluslararası Sosyal Araştırmalar Dergisi. C. 7, 31: 489-497.

Tanman, M. Baha. "İstanbul Tekkelerinin Mimari ve Süsleme Özellikleri Tipolojisi Denemeleri." Doktora Tezi, İstanbul Üniversitesi, 1990.

Tanman, M. Baha. "Merzifon Kara Mustafa Paşa Camii Şadırvanının Kubbesinde Zileli Emin'in Yarattığı “Osmanlı Dünyası” ve Bu Dünyaya Yansıyan Kişiliği." Sanat Tarihinde İkonografik Araştırmalar Güner İnal'a Armağan. Ankara: Hacettepe Üniversitesi Edebiyat Fakültesi, 1993, 491-522.

Tanman, M. Baha. “Hekimoğlu Ali Paşa Camii’ne İlişkin Bazı Gözlemler.” Oktay Aslanapa Armağanı. İstanbul: Bağlam Yayıncılık, 1996, 253-280.

Tanman, M. Baha. "Beşiktaş Mevlevihanesi’ne İlişkin Bir Minyatürün Mimarlık ve Kültür Tarihi Açısından Değerlendirilmesi.” 17. Yüzyıl Osmanlı Kültür ve Sanatı Sempozyum Bildirileri (19-20 Mart 1998 İstanbul). İstanbul: Sanat Tarihi Derneği Yayınları, 1998, 181-216.

Turani, Adnan. Sanat Terimleri Sözlüğü. Ankara: Toplum Yayınevi, 1980.

Uludağ, Süleyman. Tasavvuf Terimleri Sözlüğü. İstanbul: Kabalcı Yayınevi, 2002.

Uzun, Tolga. "19. Yüzyıl Osmanlı Duvar Resimlerinde Yeniliğin ve Değişimin Sembolü Tasvirler.” XX. Uluslararası Ortaçağ Türk Dönemi Kazıları ve Sanat Tarihi Araştırmaları Sempozyumu (0205 Kasım 2016 Sakarya) Bildiriler II. Sakarya: Sakarya Üniversitesi Yayınlar1, 2017, 852-862.

Uçar, Metin. "Berat Bekârlar Camii Duvar Resimleri." The Journal of Academic Social Science Studies (JASSS) 6/7 (2013): 1161-1184. Erişim 15 Aralık 2019, https://dx.doi.org/ 10.9761/JASSS1715.

Ünal, Rahmi Hüseyin. "Yukarı Kızılca Köyü Halil Ağa Camii.” Sanat Tarihi Dergisi VII (1994): 211-225. Ünver, A. Süheyl. Müzehhip Karamemi. İstanbul: İstanbul Üniversitesi Yayınları, 1951.

Ünver, A. Süheyl ve Gülbün Mesara. Türk Ince Oyma Sanatı. Ankara: Türkiye İş Bankası Kültür Yayınları, 1980.

Yıldırım, Savaş. “Amasya Gümüşhacıköy Türbelerindeki Kalem İşi Süslemeler.” Art Sanat 10 (2018): 293-327. Erişim 15 Aralık 2019, https://doi.org/10.26650/artsanat.2018.10.0013. 